\title{
Mirabilis expansa Growth, Yield, and Quality Traits: First US Field Trials for an Ancient, Endangered, Andean Crop
}

\author{
Miriam Kritzer Van Zant", Ken Diesburg, and David A. Lightfoot
}

Department of Plant, Soil and Agricultural Systems, Southern Illinois University, Carbondale, IL 629014415, USA

Received: May 21, 2018 / Accepted: August 8, 2018

\section{Abstract}

Crop introductions have historical importance. Ancient, endangered, Andean root and forage crop Mirabilis expansa (Ruiz and Pav.) Standl. (Nyctaginaceae), has high quality starch and protein, is drought resistant, and exhibits high morphological variation on individuals. Leaves are used for animal forage, roots for human food. Processing of the calcium oxalate could make $M$. expansa a significant modern crop. Cultivated varieties ' $L$ ' and ' $T$ ' were grown in constructed, lysimeter sand plots in southern Illinois in 2008 and 2009. There was sufficient survival and growth data for var. ' $L$ ' for testing with Repeated Measures ANOVAs. Tables of mean averages of harvest data are included for each variety. Var. ' $L$ ' plots had three levels of soil amendments plus all-sand as the control. Plant height, longest and typical axial shoot length, emerging axial and lateral shoot numbers, lamina length with and without petiole included, lamina width, and estimated herbivory, all had significance at $\boldsymbol{P}<\mathbf{0 . 0 5}$, for tracking growth in at least some soil amendments. M. expansa cultivars were therefore shown as adapted to the southern Illinois climate in the modified plots. $M$. expansa is unlikely to become invasive or a major crop where standing water can persist in the root zone.

Keywords: Mirabilis expansa (Nyctaginaceae); endangered; drought-resistant; growth; forage.

Abbreviations: Avg, mean average; CIP, Centro Internacional de la Papa; COA, combined organic amendments; diam, diameter; QCNE, Herbario Nacional; HRC, Horticulture Research Center; H-F-L, Hunyh-Feldt-Lecoutre Epsilon correction; P, peat; control, $0.0 \%$ soil amendments; $1 \mathrm{P}, 1 \%$ peat; $2 \mathrm{P}, 2 \%$ peat; 3P, 3\% peat; RCBD, randomized complete block design; SDs, standard deviations; SIU, Southern Illinois University; S, steer manure; $4-5 \mathrm{~S}, 4 \%$ and 5\% Steer Manure; $1 \mathrm{P} 3 \mathrm{~S}, 1 \%$ peat with $3 \%$ Steer Manure or Combined Organic Amendments; var., variety. Additional abbreviations are in each table's notes.

\section{Introduction}

Mirabilis expansa (Ruiz and Pav.) Standl. (Nyctaginaceae) is an ancient and endangered Andean crop with high potential to serve as a new food and fodder crop for arid lands, including both hot desert and cool mountain ecosystems. It was cultivated in both for thousands of years (Kritzer Van Zant, 2016a, 2016b, 2016c; Popenoe et al., 1989). M. expansa roots have been used for human food in many parts of the Andes (Popenoe et al., 1989). M. expansa leaves, traditionally used for animal forage, were found to contain high-quality protein in greater amounts than in the roots (Kritzer Van Zant, 2016a, 2016b, 2016c). M. expansa is rich in high quality protein and extremely fine starch. Preliminary research on $M$. expansa starch indicates it is equal to or better in quality than that of cassava (Kritzer Van Zant, 2016a, 2016b; Thanyasiriwat et al., 2013).

M. expansa appears to need porous soils (Kritzer Van Zant, 2016a). M. expansa roots often have an astringent taste, though Ecuadorian varieties may be less astringent (Popenoe et al., 1989). Astringency is probably due to the presence of needlelike raphides made of calcium oxalate crystals, which can contribute to kidney stone formation (Korth et al., 2006; Massey et al., 1993). Raphides protect crops from chewing insects. Indigenous processing methods increase palatability of the crop (Popenoe et al., 1989). Mechanical separation methods such as calcium binders and centrifuges, and/or enzyme digestion used for producing raw protein powders, might ameliorate the calcium oxalate (Coe, 2016; Ranganathan et al., 2010; Turroni et al., 2007, 2010).

Biodiversity, crucial to agricultural production, may provide solutions for creating ecologically sound agricultural systems (Di Falco and Perrings, 2005; Partap, 1992). Biodiversity is especially crucial to mountain agriculture's highly variable soils, fragile ecosystems and gene pools, inaccessibility, and nichespecific adaptations of plants to conditions (Partap, 1992; Zimmerer, 1992). In situ conservation of native crops is needed to promote biodiversity and improve the lot of small farmers in

\footnotetext{
*Corresponding author: mkvzant@gmail.com
} 
mountainous regions (Camino, 1992; Tapia, 1992).

Benefits of the Green Revolution were limited to flat and well irrigated areas (Conway, 1992; Evenson and Gollin, 2003). Resultant varieties and agronomic practices are of little use, even damaging, to arid mountain regions. In the early 1960 s and 1970s, many aid and development organizations shifted their agricultural focus for arid mountains to emphasize human need and environmental conditions. Indigenous crops have an important role in addressing these issues. Most major crops underwent most of their evolutionary development in the highlyvaried conditions of mountain regions (Zimmerer, 1992). Tapia (1992) thoroughly summarizes variable conditions relevant for agriculture in the Andes, which include the most varied conditions for a single mountain range in the world. In the Andes, as in mountain regions generally, multiple factors are causing losses of indigenous crops and erosion of genetic variability (Zimmerer, 1992). Factors include seasonal labor shortages, trade issues, and loss of land. Landslides and the world-wide demand for coca (Erythroxylum sp.) also negatively impact indigenous farming practices and crops, particularly at altitudes up to $2000 \mathrm{~m}$ (Camino, 1992; Fjeldså et al., 2005). Zones utilized in coca production overlap with where $M$. expansa was traditionally grown.

We questioned whether $M$. expansa horticultural varieties could withstand the heavy rain and drought extremes common to southern Illinois weather. Also of interest, was whether $M$. expansa could withstand typical native southern Illinois soils in better drained areas, such as hillsides and sandy soils. The question of whether there was growth through the summer was examined for two varieties of the crop. Two hypotheses, detailed in Methods below, address only var. ' $L$ ', as it was the only variety to produce sufficient data for Repeated Measures ANOVA analysis both years. This paper addresses the successful growth of M. expansa, for a two-year period, in constructed plots containing sandy soils. There is also an evaluation of the growth characters measured for this morphologically variable crop. Growth data was taken in the field while plants were growing. Harvest data was taken from a small subset of plants of var. ' $L$ ' in 2008, and of var. ' $L$ ' and var. ' $T$ ' in 2009 , which were grown on plots that received each of several different levels of soil amendments, after harvest. Positive results for growth data are given from the Repeated Measures ANOVAs (Tables 1 and 2). There was insufficient harvested material of either variety for meaningful ANOVA analysis, though a table of means is given for harvested material for each year (Supplementary Tables 1 and 2). Harvest data is presented in tables as mean averages for each variety (Supplementary Tables 1 and 2); and in graphs based on the data in those tables, with error bars representing standard deviations (Figures 4, 5, and 6; Supplementary Figures $1,2,3,4$, and 5). Var. ' $T$ ' grew in plots with slightly different levels of steer manure and peat than those used for var. ' $L$ '. Amounts of peat by itself, and steer manure by itself, were similar enough for non-statistical comparison of those two soil amendments between varieties.

Horticulturalists have been growing $M$. expansa in Belgium and Great Britain, though to date, no papers have been published from these efforts (Kritzer Van Zant, 2016a, 2016b). An experiment with the crop in Texcoco, Mexico was considered unsuccessful, as the plants failed to flower, and roots are usually harvested during flowering in the Andes (Kritzer Van Zant, 2016a, 2016b; Seminario Cunya, 1993, 2004). However, these Texcoco plants may have yielded useful forage and edible roots.

M. expansa grown in the Andes offered better forage yields than either improved alfalfa in California (Putnam, 2007) or unimproved rangeland in Utah (Perry, 2012). This is based on forage yields in an Andean trial with denser plantings than those typically used for growing roots (Kritzer Van Zant, 2016a, 2016b; Seminario Cunya, 2000, 2004). In the denser planting trial, root yields were lower than from less dense plantings intended for root harvests. However, denser planting still produced enlarged roots simultaneously with forage. M. expansa planted for roots (Rea, 1992) produced comparable yields to several potato varieties grown in Idaho (Olsen, 2004). In the root trial described by Rea, M. expansa simultaneously produced forage. It should be possible to produce $M$. expansa roots and/or forage with considerably less water and fertilizer than needed for potatoes or alfalfa (Kritzer Van Zant, 2016a, 2016b). Unfortunately, few details presented in documents describing growth of the crop in the Andes (Seminario Cunya, $1993,2000,2004)$, were directly comparable to results from our field data.

\section{Materials and Methods}

\section{Materials}

For the southern Illinois field work, var. ' $L$ ' cuttings were grown from the two stock plants. Var. ' $L$ ' stock plants were descendants from two sole survivors of plants started from seed and greenhouse grown in Illinois. Seeds of var. ' $L$ ' were sent to Kritzer Van Zant by Centro Internacional de la Papa (CIP) in Lima, Peru (CIP Accession \#208001 ARB5395). Variety ' $L$ ' was said by CIP personnel to have originated in Cajamarca, Cajamarca, Peru. However, as there were M. expansa accessions maintained there by personnel at Universidad Nacional de Cajamarca, var. ' $L$ ' may have had a different place of origin.

Variety $T$ ' was propagated from rhizomes, descendants of plants from the garden of Eloisa de la Cruz, an indigenous woman farmer in northern Ecuador. Her garden was on property in Pinchincha Province, near the road to the Tocacachi ruins. Collection of var. ' $T$ ' was made during an intensive search for cultivated M. expansa in northern Ecuador by Kritzer Van Zant. During that search, only var. ' $T$ ' was found, and only at that single location. Variety ' $T$ ' was initially propagated in Illinois from rhizomes. Stem cuttings from both varieties were next propagated as stock plants. Plants from stem cuttings were used for research in this paper, and for subsequent research to date on M. expansa amino acids and cytotoxicity (Kritzer Van Zant, 2016a).

\section{Permissions and Protections}

Upon request, seeds of var. ' $L$ ' were sent to Kritzer Van Zant by common agreement between CIP and USDA. A few of these 
Table 1. The 2008 growth data repeat measure ANOVAs positive results.

\begin{tabular}{|c|c|c|c|c|c|c|c|}
\hline $\begin{array}{l}\text { Test type } \\
\text { Interaction }\end{array}$ & $\begin{array}{l}\text { Independent } \\
\text { Variable }\end{array}$ & $\begin{array}{l}\text { Dependent } \\
\text { Variable }\end{array}$ & F Value & $\mathbf{d f}_{\mathbf{1}}, \mathbf{d f}_{\mathbf{2}}$ & $\begin{array}{l}\text { p-value H-F-L } \\
\text { adjusted }\end{array}$ & H-F-L & $\begin{array}{l}\text { p-value at } \\
.05 \text { level }\end{array}$ \\
\hline ANOVA & $\mathrm{COA}$ & PlantHt & 6.90 & 3,4 & 0.0464 & & $*$ \\
\hline Time & $\mathrm{COA}$ & PlantHt & 87.26 & 6,24 & $<0.0001$ & 0.3644 & $* *$ \\
\hline Time*COA & $\mathrm{COA}$ & PlantHt & 5.64 & 18,24 & 0.0110 & 0.3644 & $*$ \\
\hline Time & Peat & PlantHt & 27.76 & 6,30 & 0.0006 & 0.2397 & $*$ \\
\hline Time & SteerM & PlantHt & 42.69 & 6,30 & $<0.0001$ & 0.3555 & $* *$ \\
\hline Time & Terrace & PlantHt & 25.48 & 6,36 & $<0.0001$ & 0.3208 & $* *$ \\
\hline Time & $\mathrm{COA}$ & LAxShtL & 92.30 & 4,16 & $<0.0001$ & 0.4253 & $* *$ \\
\hline Time & Peat & LAxShtL & 28.46 & 4,20 & 0.0014 & 0.3016 & $*$ \\
\hline Time & SteerM & LAxShtL & 44.89 & 4,20 & 0.0002 & 0.3445 & $*$ \\
\hline Time & Terrace & LAxShtL & 40.57 & 4,24 & 0.0002 & 0.3177 & $*$ \\
\hline Time & $\mathrm{COA}$ & TAxShtL & 28.58 & 3,12 & 0.0002 & 0.6644 & $*$ \\
\hline Time & Peat & TAxShtL & 20.08 & 3,15 & 0.0004 & 0.6392 & $*$ \\
\hline Time & SteerM & TAxShtL & 29.63 & 3,15 & $<0.0001$ & 0.9844 & $* *$ \\
\hline Time & Terrace & TAxShtL & 24.69 & 3,18 & $<0.0001$ & 0.6191 & $* *$ \\
\hline Time & $\mathrm{COA}$ & AxLatSht\# & 10.73 & 3,12 & 0.0025 & 0.8250 & $*$ \\
\hline Time & Peat & AxLatSht\# & 11.40 & 3,15 & 0.0019 & 0.7225 & * \\
\hline Time & SteerM & AxLatSht\# & 10.23 & 3,15 & 0.0025 & 0.7460 & $*$ \\
\hline Time & Terrace & AxLatSht\# & 17.10 & 3,18 & 0.0002 & 0.7266 & $*$ \\
\hline Time & $\mathrm{COA}$ & In/LAxSht & 29.47 & 4,16 & 0.0001 & 0.5352 & $* *$ \\
\hline Time & Peat & In/LAxSht & 30.24 & 4,20 & $<0.0001$ & 0.5816 & $* *$ \\
\hline Time & SteerM & In/LAxSht & 28.68 & 4,20 & $<0.0001$ & 0.7118 & $* *$ \\
\hline Time & Terrace & In/LAxSht & 34.73 & 4,24 & $<0.0001$ & 0.7211 & $* *$ \\
\hline Time & $\mathrm{COA}$ & laminaLg & 5.82 & 6,18 & 0.0024 & 0.9160 & $*$ \\
\hline Time & Peat & laminaLg & 3.85 & 6,24 & 0.0078 & 1.3577 & * \\
\hline Time & SteerM & laminaLg & 4.94 & 6,24 & 0.0023 & 0.9645 & $*$ \\
\hline Time & Terrace & laminaLg & 4.46 & 6,30 & 0.0024 & 1.6054 & $*$ \\
\hline ANOVA & $\mathrm{COA}$ & laminaP & 32.37 & 3,3 & 0.0087 & & $*$ \\
\hline Time & $\mathrm{COA}$ & laminaW & 7.22 & 6,18 & 0.0005 & 1.0208 & $*$ \\
\hline Time & Peat & laminaW & 6.86 & 6,24 & 0.0002 & 1.1642 & $*$ \\
\hline Time & SteerM & laminaW & 5.66 & 6,24 & 0.0091 & 0.5500 & $*$ \\
\hline Time & Terrace & laminaW & 6.58 & 6,30 & 0.0014 & 0.6749 & $*$ \\
\hline Time & $\mathrm{COA}$ & lamWolP & 8.36 & 6,18 & 0.0191 & 0.3282 & $*$ \\
\hline Time & Peat & lamWolP & 8.17 & 6,24 & 0.0146 & 0.3055 & * \\
\hline Time & SteerM & lamWolP & 6.03 & 6,24 & 0.0022 & 0.7636 & $*$ \\
\hline Time & Terrace & lamWolP & 6.16 & 6,30 & 0.0025 & 0.6404 & * \\
\hline Time & Terrace & lamlPoW & 4.13 & 6,30 & 0.0171 & 0.6030 & * \\
\hline ANOVA & Peat & herb 0,1 & 20.89 & 2,2 & 0.0457 & & $*$ \\
\hline Time & Peat & herb 0,1 & 17.33 & 6,12 & 0.0312 & 0.2208 & $*$ \\
\hline Time & SteerM & herb 0,1 & 5.97 & 6,12 & 0.0301 & 0.5083 & * \\
\hline Time & Terrace & herb 0,1 & 13.75 & 6,18 & 0.0005 & 0.5749 & * \\
\hline Time & $\mathrm{COA}$ & $\operatorname{mass}$ & 57.00 & 6,24 & $<.0001$ & 0.3964 & $* *$ \\
\hline Time*COA & $\mathrm{COA}$ & mass & 4.74 & 18,24 & 0.0151 & 0.3964 & $*$ \\
\hline Time & Peat & mass & 21.37 & 6,30 & 0.0010 & 0.2599 & $*$ \\
\hline Time & SteerM & mass & 49.24 & 6,30 & $<0.0001$ & 0.3554 & $* *$ \\
\hline Time*SteerM & SteerM & mass & 4.38 & 12,30 & 0.0230 & 0.3554 & $*$ \\
\hline Time & Terrace & mass & 20.92 & 6,36 & $<0.0001$ & 0.4262 & $* *$ \\
\hline
\end{tabular}

Abbre viations: AxLatSht\#, axial and lateral shoot number; COA, combined organic amendments; $\mathrm{df}_{1} / \mathrm{df}_{2}$, error; herb 0,1 , herbivory coded $0,1-0=$ absent, $1=$ present; H-F-L, Huynh-Feldt-Lecoutre Epsilon correction, adjusted $\operatorname{Pr}>\mathrm{F}$ for time and the interaction; interaction, time*independent variable (specified); In/LAxSht, internodes per longest axial shoot length in first $50.8 \mathrm{~mm}$ above the soil; lamina, lamina length without petiole (laminaLg); lamina length with petiole; lamlPoW, ratio of lamina with petiole length over lamina width; laminaW, lamina width; lamWolP, ratio of lamina width over lamina with petiole length; LAxShtL, longest axial shoot length; PlantHt, plant height; $\mathrm{p}$-value, at .05 level, $\operatorname{Pr}>\mathrm{F}$ for ANOVA; SteerM, steer manure; TAxShtL, ty pical axial shoot length; *, significant; **, highly significant. 
Table 2. The 2009 growth data repeat measure ANOVAs positive results.

\begin{tabular}{|c|c|c|c|c|c|c|c|}
\hline $\begin{array}{l}\text { Test type } \\
\text { Interaction }\end{array}$ & $\begin{array}{l}\text { Independent } \\
\text { Variable }\end{array}$ & $\begin{array}{l}\text { Dependent } \\
\text { Variable }\end{array}$ & F Value & $d f_{1}, d f_{2}$ & $\begin{array}{l}\text { p-value } \\
\text { H-F-L adjusted }\end{array}$ & H-F-L & p-value \\
\hline Time & Peat & PlantHt & 6.81 & 4,20 & 0.0378 & 0.2955 & * \\
\hline Time & SteerM & PlantHt & 5.63 & 4,20 & 0.0452 & 0.3330 & * \\
\hline Time & $\mathrm{COA}$ & LAxShtL & 48.29 & 4,16 & $<0.0001$ & 0.7092 & $* *$ \\
\hline Time & Peat & LAxShtL & 40.41 & 4,20 & $<0.0001$ & 1.0162 & $* *$ \\
\hline Time & SteerM & LAxShtL & 35.54 & 4,20 & $<0.0001$ & 0.8876 & $* *$ \\
\hline Time & Terrace & LAxShtL & 33.61 & 4,24 & $<0.0001$ & 0.5571 & $* *$ \\
\hline Time & $\mathrm{COA}$ & TAxShtL & 105.04 & 4,16 & $<0.0001$ & 1.3380 & $* *$ \\
\hline Time*COA & $\mathrm{COA}$ & TAxShtL & 4.75 & 12,16 & 0.0023 & 1.3380 & * \\
\hline Time & Peat & TAxShtL & 61.99 & 4,20 & $<0.0001$ & 0.7635 & $* *$ \\
\hline Time & SteerM & TAxShtL & 49.04 & 4,20 & $<0.0001$ & 0.5995 & $* *$ \\
\hline Time & Terrace & TAxShtL & 35.10 & 4,24 & $<0.0001$ & 0.6579 & $* *$ \\
\hline Time & $\mathrm{COA}$ & AxLatSht\# & 212.57 & 4,16 & $<0.0001$ & 0.5761 & $* *$ \\
\hline Time*COA & $\mathrm{COA}$ & AxLatSht\# & 5.61 & 12,16 & 0.0095 & 0.5761 & $*$ \\
\hline Time & Peat & AxLatSht\# & 137.68 & 4,20 & $<0.0001$ & 0.4244 & $* *$ \\
\hline Time*Peat & Peat & AxLatSht\# & 5.30 & 8,20 & 0.0222 & 0.4244 & $*$ \\
\hline Time & SteerM & AxLatSht\# & 53.62 & 4,20 & 0.0002 & 0.3111 & * \\
\hline Time & Terrace & AxLatSht\# & 62.60 & 4,24 & $<0.0001$ & 0.3184 & $* *$ \\
\hline Time & $\mathrm{COA}$ & laminaLg & 25.55 & 4,16 & $<0.0001$ & 1.0377 & $* *$ \\
\hline Time*COA & $\mathrm{COA}$ & laminaLg & 3.53 & 12,16 & 0.0102 & 1.0377 & $*$ \\
\hline Time & Peat & laminaLg & 22.91 & 4,20 & $<0.0001$ & 1.0586 & $* *$ \\
\hline Time*Peat & Peat & laminaLg & 4.02 & 8,20 & 0.0055 & 1.0586 & $*$ \\
\hline Time & SteerM & laminaLg & 15.22 & 4,20 & 0.0006 & 0.5387 & * \\
\hline Time & Terrace & laminaLg & 12.13 & 4,24 & $<0.0001$ & 0.9150 & $* *$ \\
\hline ANOVA & $\mathrm{COA}$ & laminaP & 6.97 & 3,4 & 0.0457 & & $*$ \\
\hline Time & $\mathrm{COA}$ & laminaP & 15.88 & 4,16 & $<0.0001$ & 1.3054 & $* *$ \\
\hline Time & Peat & laminaP & 16.40 & 4,20 & $<0.0001$ & 0.9397 & $* *$ \\
\hline Time*Peat & Peat & laminaP & 2.76 & 8,20 & 0.0355 & 0.9397 & $*$ \\
\hline Time & SteerM & laminaP & 11.72 & 4,20 & 0.0006 & 0.6794 & $* *$ \\
\hline Time & Terrace & laminaP & 11.15 & 4,24 & $<0.0001$ & 0.8512 & $* *$ \\
\hline Time & $\mathrm{COA}$ & laminaW & 13.19 & 4,16 & $<0.0001$ & 1.1839 & $* *$ \\
\hline Time & Peat & laminaW & 12.59 & 4,20 & $<0.0001$ & 1.2686 & $* *$ \\
\hline Time & SteerM & laminaW & 13.58 & 4,20 & $<0.0001$ & 1.0939 & $* *$ \\
\hline Time & Terrace & laminaW & 13.21 & 4,24 & $<0.0001$ & 1.3674 & $* *$ \\
\hline Time & $\mathrm{COA}$ & herb 0,1 & 63.55 & 4,16 & $<0.0001$ & 0.9955 & $* *$ \\
\hline Time & Peat & herb 0,1 & 65.75 & 4,20 & $<0.0001$ & 0.9495 & $* *$ \\
\hline Time & SteerM & herb 0,1 & 63.12 & 4,20 & $<0.0001$ & 1.0712 & $* *$ \\
\hline ANOVA & Terrace & herb 0,1 & 7.43 & 1,6 & 0.0344 & & * \\
\hline Time & Terrace & herb 0,1 & 75.11 & 4,24 & $<0.0001$ & 0.9900 & $* *$ \\
\hline Time & $\mathrm{COA}$ & herb 0-4 & 189.49 & 4,16 & 0.0002 & 0.2500 & $*$ \\
\hline Time & Peat & herb $0-4$ & 200.44 & 4,20 & $<0.0001$ & 0.2500 & $* *$ \\
\hline Time & SteerM & herb $0-4$ & 157.37 & 4,20 & $<0.0001$ & 0.2500 & $* *$ \\
\hline Time & Terrace & herb $0-4$ & 273.24 & 4,24 & $<0.0001$ & 0.2500 & $* *$ \\
\hline ANOVA & $\mathrm{COA}$ & mass & 65.54 & 3,4 & 0.0007 & & $*$ \\
\hline Time & $\mathrm{COA}$ & mass & 97.57 & 4,16 & $<.0001$ & 0.5103 & $* *$ \\
\hline Time*COA & $\mathrm{COA}$ & mass & 21.16 & 12,16 & 0.0001 & 0.5103 & $* *$ \\
\hline ANOVA & Peat & mass & 37.48 & 2,5 & 0.0010 & & $*$ \\
\hline Time & Peat & mass & 105.07 & 4,20 & $<.0001$ & 0.8146 & $* *$ \\
\hline Time*Peat & Peat & mass & 24.46 & 8,20 & $<.0001$ & 0.8146 & $* *$ \\
\hline ANOVA & SteerM & mass & 6.59 & 2,5 & 0.0360 & & $*$ \\
\hline Time & SteerM & mass & 35.76 & 4,20 & $<.0001$ & 0.05489 & $* *$ \\
\hline Time*SteerM & SteerM & mass & 8.22 & 8,20 & 0.0023 & 0.05489 & $*$ \\
\hline Time & Terrace & mass & 8.83 & 4,24 & 0.0190 & 0.2882 & $*$ \\
\hline
\end{tabular}

Abbre viations: AxLatSht\#, axial and lateral shoot number; $\mathrm{COA}$, combined organic amendments; $\mathrm{df}_{1} / \mathrm{df}_{2}$, error; herb 0,1 , herbivory coded 0,1 - absent $=0$, present $=1$; herb $0-4$, herbivory coded with five levels - no noticeable herbivory $=0$, noticeable though insignificant $=1$, slight $=2$, moderate $=3$, and heavy $=4$; lamina, lamina length with petiole; H-F-L, Huynh-Feldt-Lecoutre Epsilon correction, adjusted $\operatorname{Pr}>\mathrm{F}$ for time and the interaction; interaction, time*independent variable (specified); laminaLg, lamina length without petiole; laminaW, lamina width; LAxShtL, longest axial shoot length; PlantHt, plant height; $p$-value, at .05 level, $\operatorname{Pr}>\mathrm{F}$ for ANOVA; SteerM, steer manure; TAxShtL, typical axial shoot length*, significant; **, highly significant. 
seeds were shared with Colorado researchers (Vepachedu et al., 2003). Variety ' $T$ ' was brought back to the United States with permission from the Ecuadorian government, under Ecuadorian permit \#023-IC-FLO-DNBAP/MA, in conjunction with Kritzer Van Zant's then host institution, Herbario Nacional (QCNE), in Quito. Guachuiun, Puente and de la Cruz signed Human Subjects Forms protecting their rights and those of Ecuador, along with the research rights of Kritzer Van Zant.

\section{Growth of M. expansa in the Field}

M. expansa was grown outdoors in sand plots (Supplementary Figure 6; Kritzer Van Zant 2016a Appendix B-1). These plots had lain fallow for several years prior to 2008. These plots were originally set up for research on golf turf, 10-15 years prior to first use of them for growing $M$. expansa. Plots were each $2 \times 4$ $\mathrm{m}$, spaced $1 \mathrm{~m}$ apart, and arranged in three consecutive terraces. Terrace I, II and III slope gradually downward to the east, along the same hill, with Terrace I at the top of the hill. Plots were amended at the time of construction with varied percentages of peat and steer manure. Eight levels of treatments, including allsand controls, were repeated on each terrace when constructed. As not all of the original plot types were used, plots used for $M$. expansa made up a modified replicated randomized complete block design (RCBD). Constructed root zones in the plots were $30.5 \mathrm{~cm}$ deep. Plots were made with $96-100 \%$ sand overlaying a $10.2 \mathrm{~cm}$ deep layer of $6.4 \mathrm{~mm}$ sized gravel. A drainage pipe was installed at the base of the gravel layer. Lysimeters were incorporated into each plot at construction. Each plot drained separately into a bottle, which overflowed into a channel alongside and $2 \mathrm{~m}$ below the plots, so little or no leaching occurred between plots and there was little standing water. Not all lysimeters were still functioning at the time M. expansa was growing in the plots, so lysimeter measurements were not taken. However, each plot still drained well, and the lysimeter construction reduced overflow of water among plots.

From each terrace, a single plot for each of three soil amendments, plus an all-sand control, were used for the var. ' $L$ ' experiments in 2008 (Table 1 and Supplementary Table 1; Figure 4 and Supplementary Figure 3). This made four treatments. These same plots were used again for Experiment I with var. ' $L$ ' in 2009 (Table 2 and Supplementary Table 2; Figure 5, and Supplementary Figures 1, 3, and 4). Thirty-two plants were measured each year for the repeated experiments with var. ' $L$ '. Averaging was done separately for var. ' $L$ ' for each year. This helped to compensate for discrepancies in planting, measuring, and survivorship.

Experiment IV plots had var. ' $T$ ' plants exclusively in 2009 (Supplementary Table 2; Figure 6 and Supplementary Figures 2 and 5). For growing var. ' $T$ ', two levels of treatments were used, different from those used for var. ' $L$ ', and excluding the all-sand controls. Experiment IV plot types were $4 \%$ steer manure (4S) and $2 \%$ peat (2P), and were on Terraces I (upper) and II (middle). Experiment IV plots were also planted with four plants each. Additional plots on the same terraces were also planted with each variety in various combinations. However, results from plots containing both varieties, are only included as part of our general observations. The additional plots also provided material for nutrition and cytotoxicity research on the crop.

Four soil samples were taken in 2011 from plot treatments matching those which had been used for the var. ' $L$ ' statistically analyzed 2008 and 2009 experiments. These samples were tested for soil nitrogen concentrations in 2012 at the Soil and Plant Testing Laboratory at University of Missouri Extension (http:// soilplantlab.missouri.edu/soil/). Each soil sample came from a different plot type on different terraces, so results were not averaged. Nitrogen concentrations for different plots were low and did not vary in any pattern that correlated with the original plot amendments. They are only mentioned as a window into the overall condition of the plots. No additional samples from these plots have been subsequently tested for nitrogen. However, differences in weed cover among plot treatments indicated that there were still differences among plot types just prior to and during the Mirabilis experiments. These plant community differences were probably due more to persistent changes in soil structure, than to levels of nitrogen present in the plots.

Each plant received a single pint of mushroom composted horse manure, at the time of planting. Manure was covered with a small amount of sandy media from the plot being planted, beneath each plant. Manure had been added to increase the possibility that subtle differences that might remain between plots with different levels of soil amendments, would be apparent in the results. Manure was aged for the same length of time within each year for all plants. However, in 2009 the manure had aged an additional year over 2008 .

\section{Harvest Data}

Growth data had consisted of the measurements taken while the plants were still growing in the field and were analyzed in Repeated Measures ANOVAs for var. ' $L$ ' (Tables 1 and 2; Figures 1, 2, and 3). Harvest data (Supplementary Tables 1 and 2; Figures 4, 5, and 6, Supplementary Figures 1, 2, 3, 4, and 5) were taken after plants were dug up at the end of each season. Harvest data for 2008 and 2009 were insufficient in quantity for meaningful ANOVA analysis for either variety, and therefore were considered separately from growth data. Harvest data were compared as mean averages between the two varieties, from each plot type, for plots modified with similar amounts of peat or steer manure, $5 \mathrm{~S}$ and $3 \mathrm{P}$ for var. ' $L$ ', to $4 \mathrm{~S}$ and $2 \mathrm{P}$ for var. ' $T$ '. For var. ' $L$ ', within each year, the combined $1 \mathrm{P} 3 \mathrm{~S}$ and all-sand control plots were also levels of soil amendments available to compare to $5 \mathrm{~S}$ and $3 \mathrm{P}$. Harvest data for var. ' $L$ ' was grown in 2008 (Supplementary Table 1; Figure 4, Supplementary Figure 3) and 2009 (Supplementary Table 2; Figure 5; Supplementary Figures 1 and 4). Harvest data for var. ' $T$ ' came exclusively from the plants grown in Experiment IV in 2009 (Supplementary Table 2; Supplementary Figures 2 and 5).

Measurements were taken before and after harvested specimens were dried. Plants were dried hanging from ropes in a barn, to mimic traditional drying practices. Drying time was shorter in 2008 than in 2009 though both periods of time exceeded the typical eight days minimum drying time reported 
by indigenous people. Whole dried plants were weighed, then herbage separated from below ground portions of the plants and re-weighed separately. Harvest data for both years consisted of whole plant weights prior to and post drying, percentage change in dry weight, and above-ground and underground portions of the plant as dry weight.

Root size was averaged for each variety, for each soil amendment from which material was harvested (Supplementary Tables 1 and 2). Results for root size from 2009 (Supplementary Table 2), from $4 \mathrm{~S}$ and $2 \mathrm{P}$ plots from which var. ' $T$ ' roots were harvested (Supplementary Table 2; Figure 6, Supplementary Figures 2 and 5), are again compared with results for var. ' $L$ ' taken from $5 \mathrm{~S}$ and $3 \mathrm{P}$ plots (Supplementary Table 2; Figure 5, Supplementary Figures 1 and 4), from the same year. Two plants were taken for each kind of soil amendment, one each from separate plots on different terraces. Remaining plants were left in the ground to see if they would winter over. However, var. ' $T$ ' was not available from $2 \mathrm{P}$ plots on the upper terrace, so only a single var. ' $T$ ' plant was harvested from a $2 \mathrm{P}$ plot on the middle terrace. Thus no SDs could be computed for $2 \mathrm{P}$ or upper terrace, on graphs for var. ' $T$ ' (Supplementary Figures 2 and 5).

Additional harvest variables were added in 2009 along with var. ' $T$ ' data (Supplementary Table 2; Supplementary Figures $1,2,3,4$, and 5). They are root length and root diameter in $\mathrm{cms}$ (Supplementary Table 2; Supplementary Figures 1 and 2), and the non-continuous character of position of the widest portion of the root mass (Supplementary Table 2). For this last character, each harvested root mass was visually divided into four zones or levels, from top to bottom as they had been oriented in the soil, and the widest of these zones was noted.

Harvest data results (Supplementary Tables 1 and 2) are otherwise self-explanatory and non-statistical, so harvest results are not much discussed in the body of the paper below. Description is given for the Harvest tables in Kritzer Van Zant (2016a Appendices B-4, B-5 and B-6).

\section{Analyses and Variables-Field Growth Data}

Results of the ANOVA analyses, are divided into growth data from the var. ' $L$ ' experiments in 2008 (Table 1; Figure 1) and 2009 (Table 2; Figures 2 and 3). Growth data for var. ' $L$ ' (Tables 1 and 2; Figures 1, 2, and 3) resulting from the ANOVAs between independent variables, are labelled "ANOVA". ANOVAs for the same data through time are labelled "time", and ANOVAs for the interaction of time with each independent variable, are labelled as "time*independent variable" (Tables 1 and 2). An example is "time* peat". Only positive results of the statistical analyses are presented below. Negative results are in extended tables in Kritzer Van Zant (2016a Appendix B-8). In addition, there are three figures of graphs given in this paper (Figures 1, 2, and 3), illustrating the most compelling positive "ANOVA" results from the Repeated Measures analyses, for the var. ' $L$ ' growth data.

$M$. expansa var. ' $L$ ' field data was analyzed with Repeated Measures 2-way ANOVAs in SAS (Cary, NC), separately for 2008 and 2009. The decision to use Repeated Measures
ANOVAs, sometimes used in ecological studies, resulted from consultation with biological statistician John D. Reeve of SIUC. Repeated Measures ANOVAs take into account the lack of independence between measurements on the same individuals, by applying a correction to time and the interaction. Regular ANOVAs require an assumption of independence between measurements. The two independent variables in each Repeated Measures analysis, were treatment meaning a soil amendment or terrace, and time across the growing season in fixed intervals. The intervals for measurement were different for each year. Repeated measurements may be correlated, so the tests can need adjustment. Repeated measures analysis fixes the correlation issue, using correction factors. Therefore, the H-F-L (Huynh-Feldt-Lecoutre Epsilon) value was used to alter the degrees of freedom for the time, and treatment $\mathrm{x}$ time interaction tests, making them more conservative. H-F-L is considered strict. When the H-F-L is 1, tests don't need adjustment. Since the treatment test is not affected by correlated observations, no correction is applied to it, making it similar to a 1-way ANOVA. However, since the correction is applied to time, one of the two independent variables, 2-way Repeated Measures ANOVAs are different from regular 2-way ANOVAs. In this design, treatment, time, and the treatment $\mathrm{x}$ time interaction, are all fixed effects. T-tests and tables with means are more traditionally included in agricultural field research papers. Repeated Measures ANOVAs made it possible to consider the subtle variations in plot treatments through time for each measured character, in spite of the lack of independence for measurements on the same individuals taken across the growing season. These analyses provided three kinds of results, labeled in tables 1 and 2 as ANOVAs, time, and the interaction of time with each plot treatment as independent variables, ie: time x peat in the text, or time*peat in tables. The treatment results designated ANOVA, use the mean for each subject over time, though they include no measurement of time itself. Time and the interaction, include both time and repeated measurements, which SAS refers to as "Within Subjects". As these tests address measurements from each period of time in which growth measurements were taken, for each pair of variables, it is not practical to include means of individual measurements at particular points in time in tables. Separate tables of means for each kind of growth measurement, at each time of measurement, would create confusion when interpreting this data set, as the purpose is to show the growth of M. expansa through time, and the usefulness of each measurement through the season. Means considered separately at each point in time would not give a cohesive picture. Three graphs produced by SAS for the analyses are presented (Figures 1, 2, and 3). They illustrate some of the strongest patterns in the data across the season from both years. Graphs for each combination of variables are in Kritzer Van Zant (2016a Appendix B-9).

Growth rates were analyzed separately for several measured dependent variables. Included dependent variables for 2008 were the continuous characters: axial and lateral shoot number counted on stems up to $5 \mathrm{~cm}$ above the soil surface; estimated mass; plant height; longest axial shoot; typical axial shoot length; internodes per longest axial shoot; lamina length with and without petioles; and lamina width. In 2008 the only non- 
continuous character was estimated herbivory coded absent (0) or present (1). Continuous characters were measured in $\mathrm{cm}$ or $\mathrm{cm} 3$ unless otherwise stated.

Some 2008 variables were excluded in 2009 including, counting internodes on the longest axial shoot, and ratios for lamina lengths and widths, as they had given little useful information the previous year. Independent variable, starting size of the plant, had three levels - small, medium, or large. Independent variable position in the subplots had four levels- $-\mathrm{NW}$, SW, NE, or NW. Starting size and position in the subplots were both dropped in 2008, prior to the ANOVA analysis, after preliminary t-tests showed they had no effect.

Herbivory 0, 1 coding had little meaning in the statistical analyses as all plants were subjected to at least some herbivory. Therefore, in 2009 though herbivory was measured as present or absent again to compare to the 2008 data, it was also separately measured on a scale for degree of herbivory with five levels - no noticeable herbivory (0), noticeable though insignificant (1), slight (2), moderate (3) and, heavy (4).

In addition, in 2009 the largest and most typical or averagesized leaves were measured for the continuous characters of length of the lamina alone, length of the lamina with petiole included, and width of the lamina at the widest point. The lamina measurements and herbivory estimates were taken for each plot in 2009, instead of for each plant as in 2008. Lamina measurements were taken for both largest and average leaves, because $M$. expansa leaves appear to exhibit indefinite growth in the field, greenhouse, and herbarium. All lamina measurements taken for individual plants were averaged for each plot prior to running the ANOVAs, to compensate for this difference in how measurements were taken.

\section{Analyses and Variables-Harvest Data}

Means for harvest data (Supplementary Tables 1 and 2) were confirmed, and graphs with SDs for that same data (Figures 4, 5 and 6, Supplementary Figures 1, 2, 3, 4 and 5), were computed using Microsoft Excel (2016). Means for the harvest data are presented for var. ' $L$ ' in 2008 (Supplementary Table 1; Figure 4, Supplementary Figure 3), and for both varieties in 2009 (Supplementary Table 2; Figure 5 and 6; Supplementary Figures 1, 2, 4 and 5). $\mathrm{Y}$ axes for graphs, of the mean harvest weights are in kgs (Figures 4, 5 and 6), lengths are in cms (Supplementary Figures 1 and 2), and percentage weight change for whole plants after drying are in percent (Supplementary Figures 3, 4, and 5). Error bars in these graphs represent standard deviations (SDs) of the means.

\section{Hypotheses}

In addition to the general question, would M. expansa' grow in the outdoor sand plots across the growing season, two hypotheses were addressed for var. ' $L$ ', prior to the analyses of the field growth data for $M$. expansa. Var. ' $T$ ' could only be considered for the general question concerning growth. Only var. ' $L$ ' gave sufficient data for a meaningful ANOVA analysis of the characters measured, to see if there were significant differences among levels of soil amendments. Both hypotheses were applied to var. ' $L$ ' grown in 2008 and 2009 in southern Illinois. Repeated Measures ANOVA results were applied separately to the hypotheses for var. ' $L$ ' for each year. For each analysis, $p$ values of $5 \%$ or less indicated significance, and $0.01 \%$ or less indicated high significance. The hypotheses were: $\mathrm{H} 0=$ amounts of peat applied at the time of plot construction have no effect on growth of $M$. expansa horticultural varieties. $\mathrm{H} 1=$ amounts of peat applied at the time of plot construction have an effect on growth of M. expansa horticultural varieties; $\mathrm{H} 0=$ amounts of Steer Manure applied at the time of plot construction have no effect on growth of M. expansa horticultural varieties. $\mathrm{H} 1=$ amounts of Steer Manure applied at the time of plot construction have an effect on growth of $M$. expansa horticultural varieties.

\section{Results and Discussion}

\section{Positive Results for Analyses of Variance, Time, and Interac- tion of Time with Independent Variables}

There was a great deal of variation in means at different points in time and for different pairs of variables and levels, which the Repeated Measure ANOVA results made sense of. These contradictions can be seen in 96 graphs which resulted from the Repeated Measures analyses of the field data, in Kritzer Van Zant (2016a Appendix B-9). The Repeated Measures ANOVA analyses were particularly useful for finding significant results for the variable of time itself, which T-tests could not have addressed.

\section{ANOVAs}

ANOVAs for the 2008 growth data, were for Treatment only (Table 1), and did not include time as a separate variable. They were significant for the independent variable COA (combined organic amendments) for plant height $\left(\mathrm{F}=06.90_{03,04}, \mathrm{H}-\mathrm{F}-\mathrm{L}\right.$ adjusted $\mathrm{p}=0.0464$; Figure 1$)$, lamina with petiole length $(\mathrm{F}=$ $32.37_{03,03}, \mathrm{H}-\mathrm{F}-\mathrm{L}$ adjusted $\left.\mathrm{p}=0.0087\right)$, and for the independent variable peat $\left(\mathrm{F}=20.89_{02.02}, \mathrm{H}-\mathrm{F}-\mathrm{L}\right.$ adjusted $\left.\mathrm{p}=0.0457\right)$ for herbivory coded 0,1 (Table 1 ; Figure 1).

ANOVAs for the 2009 growth data (Table 2) were significant for: the independent variable COA for lamina with petiole length $\left(\mathrm{F}=06.97_{03,4}, \mathrm{H}-\mathrm{F}-\mathrm{L}\right.$ adjusted $\left.\mathrm{p}=0.0457\right)$ and estimated mass $\left(F=65.54_{03,4}, H-F-L\right.$ adjusted $p=0.0007$; Figure 2); the independent variable Peat for estimated mass $(\mathrm{F}=37.4802,05$, H-F-L adjusted $p=0.0010$ ); the independent variable steer manure for estimated mass $\left(\mathrm{F}=6.59_{02,05}, \mathrm{H}-\mathrm{F}-\mathrm{L}\right.$ adjusted $\mathrm{p}=$ 0.0360 ; Figure 3 ); and the independent variable terrace for herbivory coded $0,1\left(\mathrm{~F}=07.43_{01,06}\right.$, H-F-L adjusted $\left.\mathrm{p}=0.0344\right)$ (Table 2).

No one character gave consistent results both years for any of the soil amendments in the Repeated Measures ANOVA for any treatment without time as a separate independent variable. Increases in plant height for all the treatments over the control became more pronounced as the growing season continued in some plot types (Figures 1 and 2). However, the 3\% $\left(\mathrm{v}^{3} / \mathrm{v}^{3}\right)$ steer manure amended plots, at the time of final measurement in 


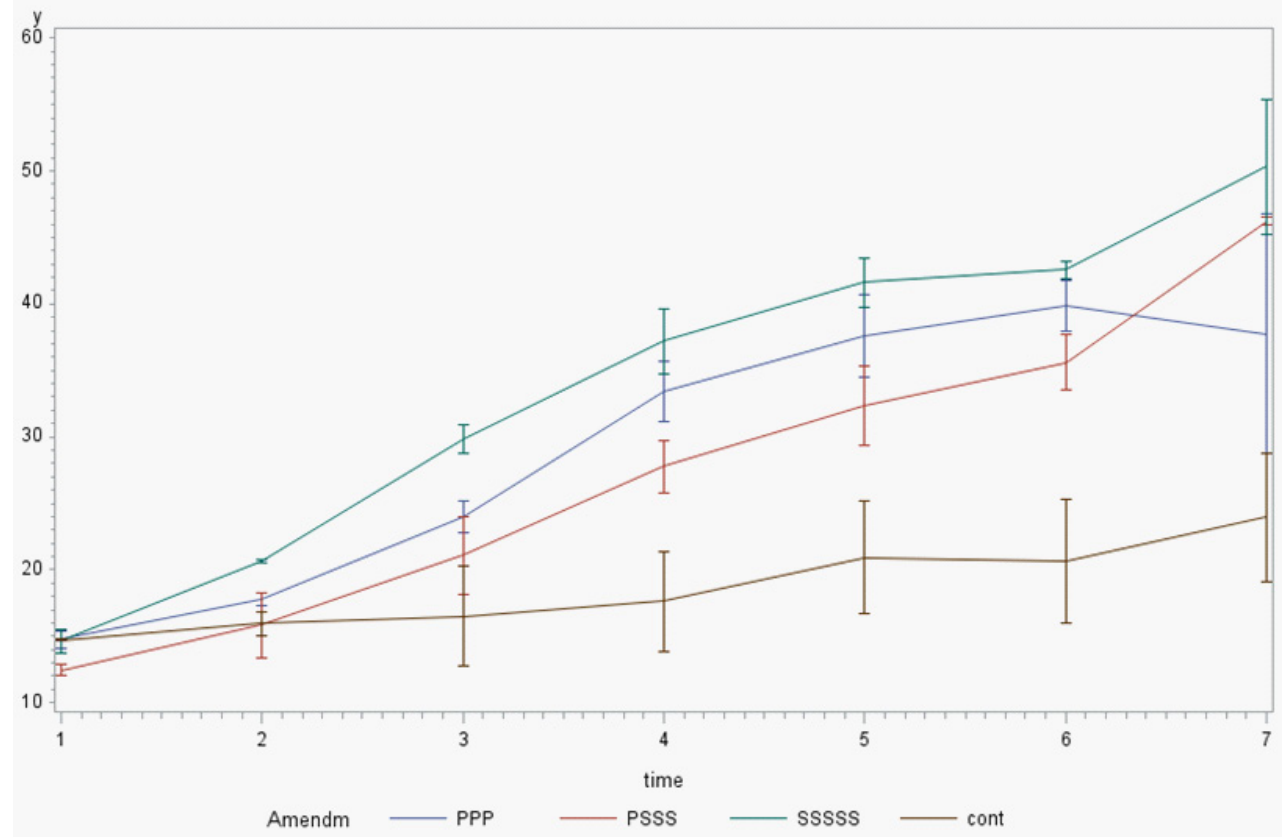

Figure 1. Chart of effect of COA on var. ' $L$ ' plant height, grown in outdoor sand plots in 2008. x-axis: Measurement dates: 1, 19Jul; 2, 2Aug and 4Aug; 3, 17Aug and 19Aug; 4, 2Sep and 3Sep; 5, 16Sep and 17Sep; 6, 2Oct; 7, 14Oct. y-axis: plant height in $\mathrm{cm}$. Abbreviations: amendm/COA, combined organic amendments; PPP, 3\% peat; PSSS, $1 \%$ peat with 3\% steer manure; SSSSS, $5 \%$ steer manure; cont, allsand control. Amendments consist of steer manure and/or peat added at time of plot construction. First measurement taken 2 wks post planting.

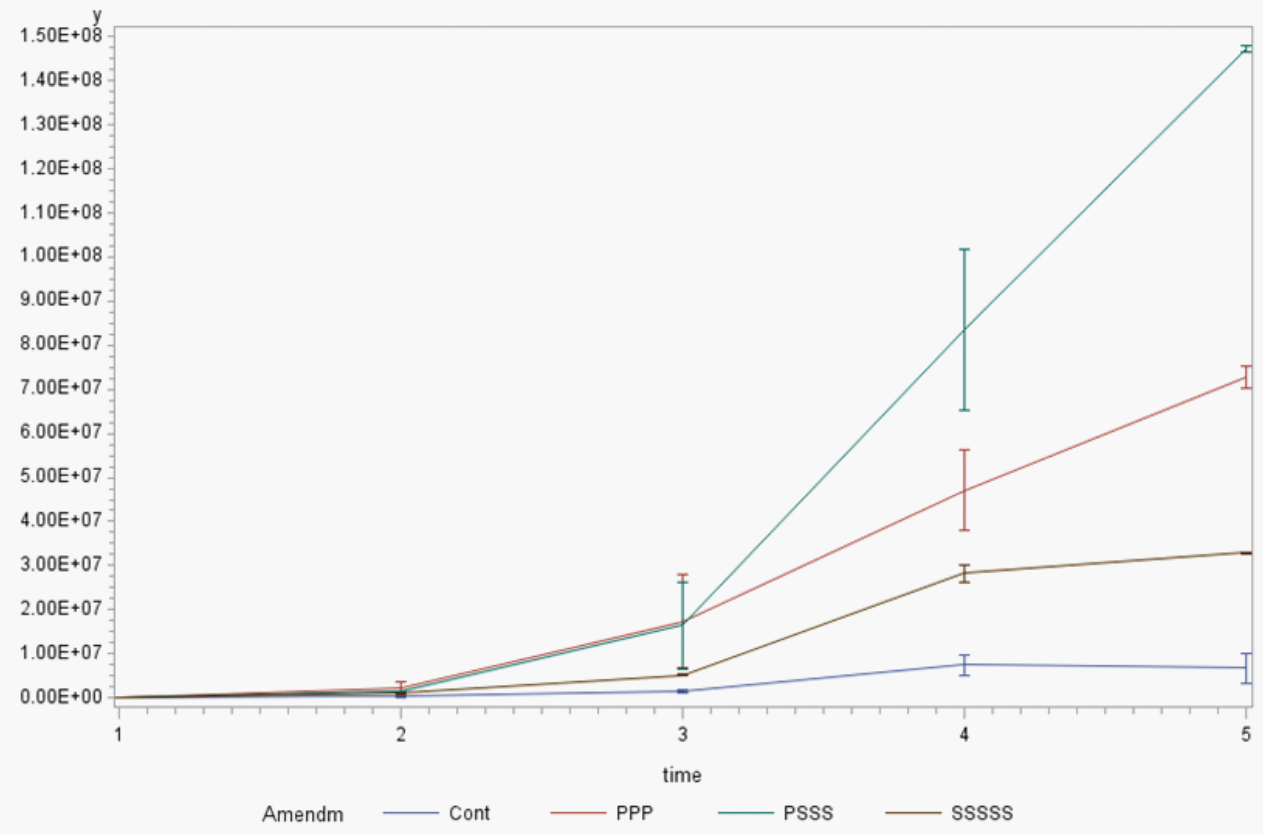

Figure 2. Chart of effect of COA on var. ' $L$ ' Estimated Mass, grown in outdoor sand plots in 2009. x-axis: Measurement dates: 1, 20Jun; 2, 19Jul; 3, 16Aug; 4, 18Sep; 5, 18Oct. y-axis: estimated mass in $\mathrm{cm}^{3}$. Abbreviations: amendm/COA, combined organic amendments; PPP, 3\% peat; PSSS, $1 \%$ peat with 3\% steer manure; SSSSS, $5 \%$ steer manure; cont, all-sand control. Amendments consist of steer manure and/or peat added at time of plot construction. First measurement taken 4 wks post planting. 


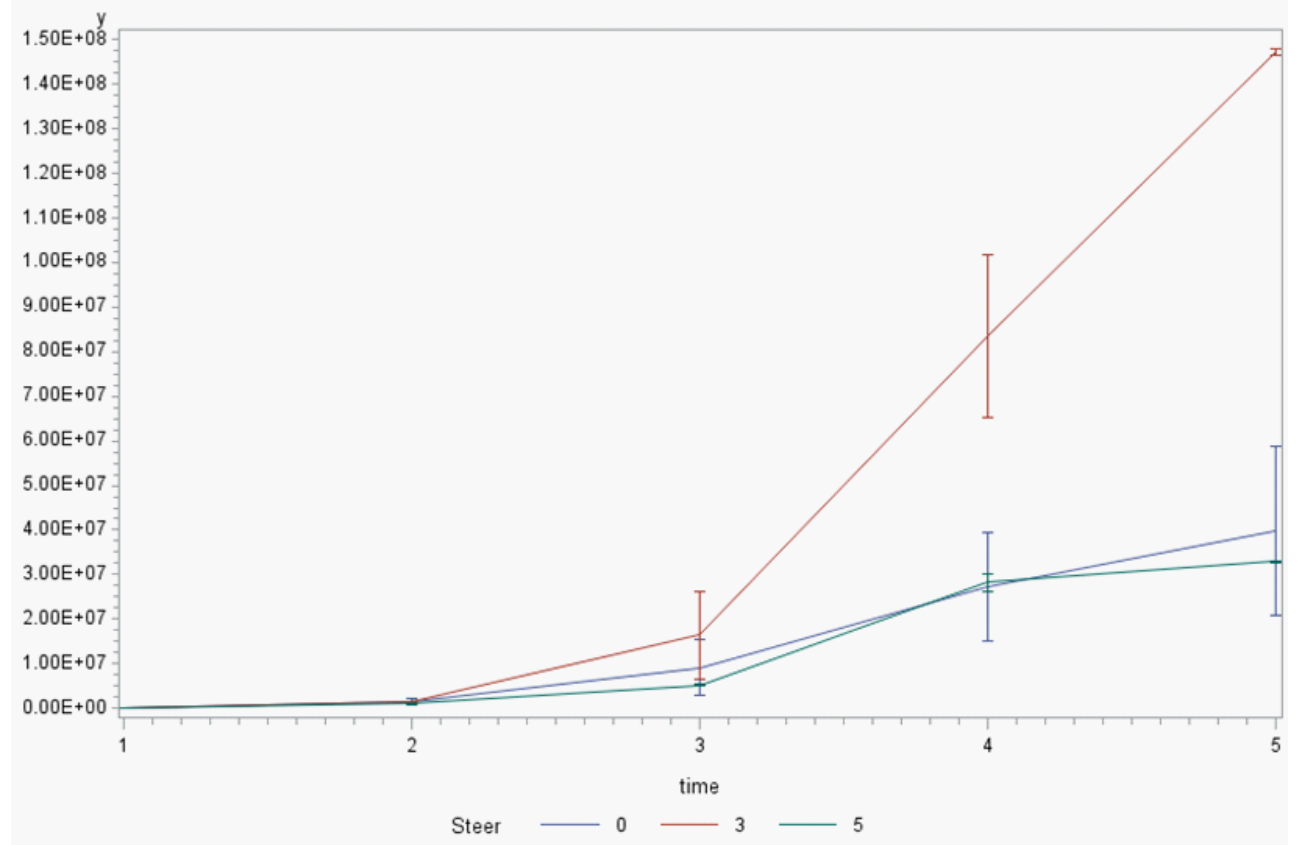

Figure 3. Chart of effect of steer manure on var. ' $L$ ' estimated mass, grown in outdoor sand plots in 2009. x-axis: measurement dates: 1, 20Jun, 2, 19Jul, 3, 16Aug, 4,18Sep, 5, 18Oct. y-axis: estimated mass in $\mathrm{cm}^{3}$. Abbreviations: Steer, steer manure; $0,0 \%$ steer manure; 3, 3\% steer manure; 5, 5\% steer manure. steer manure added at time of plot construction. First measurement taken 4 wks post planting.

2009 , gave about a $150 \%\left(\mathrm{~cm}^{3} / \mathrm{cm}^{3}\right)$ increase in estimated mass over both the control and 5\% steer manure amended plots (Figure 3). This may show that too little or too much of the nutrients in steer manure limited growth. An alternative or additional explanation is that the intermediate $3 \%$ steer manure amended plots had the effect of retaining sufficient moisture to help $M$. expansa grow, though not enough to interfere with growth.

Herbivory results in the first set of ANOVAs for treatment were also contradictory. Herbivory results in ANOVAs for treatment may have been affected by insect life cycles, as they were higher for all treatments in the middle of the growing season.

The greatest difference for lamina with petiole length in the first set of ANOVAs for combined organic amendments, was at mid-July in 2009 , when $1 \%$ peat with $3 \%$ steer manure had roughly $75 \%$ greater length than the control, $5 \%$ steer manure was roughly $50 \%$ longer than the control, and $3 \%$ peat fell between the other two treatments, giving all treatments more length than the control (Kritzer Van Zant 2016a Appendix B-6 Figure 81). Similar patterns of all treatments producing greater growth than the control, can be seen for $1 \%$ peat and 3\% steer manure on plant height in 2008 (Figure 1) and on estimated mass in 2009 (Figure 2).

Time: for the 2008 growth data was highly significant for COA, for plant height $\left(\mathrm{F}=87.26_{06,24}, \mathrm{H}-\mathrm{F}-\mathrm{L}\right.$ adjusted $\mathrm{p}=$ $<0.0001$; Figure 1), longest axial shoot length $\left(\mathrm{F}=92.30_{4,16}\right.$, H-F-L adjusted $p=<0.0001$ ), internodes per longest axial shoot length $\left(\mathrm{F}=29.47_{04,16}, \mathrm{H}-\mathrm{F}-\mathrm{L}\right.$ adjusted $\left.\mathrm{p}=0.0001\right)$ and estimated mass $\left(\mathrm{F}=57.00_{06224}, \mathrm{H}-\mathrm{F}-\mathrm{L}\right.$ adjusted $\left.\mathrm{p}=<0.0001\right)$ (Table 1). Time for the 2008 growth data was significant for combined or- ganic amendments for typical axial shoot length $\left(\mathrm{F}=25.58_{03.12}\right.$, H-F-L adjusted $p=0.0002$ ), axial and lateral shoot number $\left(\mathrm{F}=10.73_{03.12}, \mathrm{H}-\mathrm{F}-\mathrm{L}\right.$ adjusted $\left.\mathrm{p}=0.0025\right)$; lamina length $(\mathrm{F}$ $=05.82_{6,18}$, H-F-L adjusted $\left.\mathrm{p}=0.0024\right)$; lamina width $(\mathrm{F}=$ $07.22_{06,18}, \mathrm{H}-\mathrm{F}-\mathrm{L}$ adjusted $\left.\mathrm{p}=0.0005\right)$; and lamina width over lamina with petiole length $\left(\mathrm{F}=08.36_{06,18}, \mathrm{H}-\mathrm{F}-\mathrm{L}\right.$ adjusted $\mathrm{p}=$ 0.0191) (Table 1).

Time for the 2009 growth data was highly significant for COA for: longest axial shoot length ( $\mathrm{F}=48.29_{04,16}, \mathrm{H}-\mathrm{F}-\mathrm{L}$ adjusted $\mathrm{p}=<0.0001)$; typical axial shoot length $\left(\mathrm{F}=105.04_{04,16}\right.$, H-F-L adjusted $\mathrm{p}=<0.0001$ ); axial and lateral shoot number $\left(\mathrm{F}=212.57_{04,16}, \mathrm{H}-\mathrm{F}-\mathrm{L}\right.$ adjusted $\left.\mathrm{p}=<0.0001\right)$; lamina length $\left(\mathrm{F}=25.55_{04,16}, \mathrm{H}-\mathrm{F}-\mathrm{L}\right.$ adjusted $\left.\mathrm{p}=<0.0001\right)$; lamina with petiole length $\left(\mathrm{F}=15.88_{04,16}, \mathrm{H}-\mathrm{F}-\mathrm{L}\right.$ adjusted $\left.\mathrm{p}=<0.0001\right)$; lamina width $\left(\mathrm{F}=13.19_{0416}, \mathrm{H}-\mathrm{F}-\mathrm{L}\right.$ adjusted $\left.\mathrm{p}=<0.0001\right)$; herbivory coded $0,1\left(\mathrm{~F}=63.55_{04}, 16, \mathrm{H}-\mathrm{F}-\mathrm{L}\right.$ adjusted $\left.\mathrm{p}=<0.0001\right)$; and estimated mass $\left(\mathrm{F}=97.57_{04,16}, \mathrm{H}-\mathrm{F}-\mathrm{L}\right.$ adjusted $\left.\mathrm{p}=<0.0001\right)$ (Table 2). Time for the 2009 growth data, was significant for COA for herbivory coded $0-4\left(\mathrm{~F}=189.49_{04,16}, \mathrm{H}-\mathrm{F}-\mathrm{L}\right.$ adjusted $\mathrm{p}=0.0002)$ (Table 2).

Clearly, the analysis of the effect of time indicates multiple measurements are useful to track growth in var. ' $L$ ' throughout the growing season. However, which are best is less clear, when comparing results between 2008 and 2009, or between soil amendment within and between years, or for each level of soil amendment at different points in time. Considering how varied expression is in the Nyctaginaceae, this is not a surprise. We have witnessed extremely high variation within wild type individuals of M. expansa, on herbarium sheets. For combined 
organic amendments, consistently significant results for growth through time, between years, were seen for longest axial shoot length, typical axial shoot length, axial and lateral shoot numbers counted on stems up to $5 \mathrm{~cm}$ above the soil surface, lamina length not including petiole length, lamina width, and estimated mass.

Time for the 2008 growth data, was highly significant for peat only for internodes per longest axial shoot length $(\mathrm{F}=$ $30.24_{04,2}$, H-F-L adjusted $\mathrm{p}=<0.0001$ ) (Table 1). However, time for the 2008 growth data, was significant for peat for: plant height $\left(\mathrm{F}=27.76_{06,30}, \mathrm{H}-\mathrm{F}-\mathrm{L}\right.$ adjusted $\left.\mathrm{p}=0.0006\right)$; longest axial shoot length $\left(\mathrm{F}=28.46_{04,20}, \mathrm{H}-\mathrm{F}-\mathrm{L}\right.$ adjusted $\left.\mathrm{p}=0.0014\right)$; typical axial shoot length $\left(\mathrm{F}=20.08_{03,15}, \mathrm{H}-\mathrm{F}-\mathrm{L}\right.$ adjusted $\mathrm{p}=$ 0.0004); axial and lateral shoot number $\left(\mathrm{F}=11.40_{03,15}, \mathrm{H}-\mathrm{F}-\mathrm{L}\right.$ adjusted $\mathrm{p}=0.0019)$; lamina length $\left(\mathrm{F}=03.85_{06,24}, \mathrm{H}-\mathrm{F}-\mathrm{L}\right.$ adjusted $\mathrm{p}=0.0078)$; lamina width $\left(\mathrm{F}=06.86_{06,24}, \mathrm{H}-\mathrm{F}-\mathrm{L}\right.$ adjusted $\mathrm{p}=0.0002)$; lamina width over lamina with petiole length $(\mathrm{F}=$ $08.17_{06.24}, \mathrm{H}-\mathrm{F}-\mathrm{L}$ adjusted $\left.\mathrm{p}=0.0146\right)$; herbivory coded $0,1(\mathrm{~F}$ $=17.33_{06,12}, \mathrm{H}-\mathrm{F}-\mathrm{L}$ adjusted $\left.\mathrm{p}=0.0312\right)$; and estimated mass $(\mathrm{F}$ $=21.37_{06,30}, \mathrm{H}-\mathrm{F}-\mathrm{L}$ adjusted $\left.\mathrm{p}=0.0010\right)($ Table 1$)$.

Time for the 2009 growth data, was highly significant for peat for: longest axial shoot length $\left(\mathrm{F}=40.41_{04.20}, \mathrm{H}-\mathrm{F}-\mathrm{L}\right.$ adjusted $\mathrm{p}=<0.0001)$; typical axial shoot length $\left(\mathrm{F}=61.99_{04,20}\right.$, H-F-L adjusted $\mathrm{p}=<0.0001$ ); axial and lateral shoot number $\left(\mathrm{F}=137.68_{04,20}, \mathrm{H}-\mathrm{F}-\mathrm{L}\right.$ adjusted $\left.\mathrm{p}=<0.0001\right)$; lamina length $\left(\mathrm{F}=22.91_{04,20}, \mathrm{H}-\mathrm{F}-\mathrm{L}\right.$ adjusted $\left.\mathrm{p}=<0.0001\right)$; lamina with petiole length $\left(\mathrm{F}=16.40_{04,20}, \mathrm{H}-\mathrm{F}-\mathrm{L}\right.$ adjusted $\left.\mathrm{p}=<0.0001\right)$; lamina width $\left(\mathrm{F}=12.59_{04,20}\right.$, H-F-L adjusted $\left.\mathrm{p}=<0.0001\right)$; herbivory coded $0,1\left(\mathrm{~F}=65.75_{04,20}, \mathrm{H}-\mathrm{F}-\mathrm{L}\right.$ adjusted $\left.\mathrm{p}=<0.0001\right)$; herbivory coded $0-4\left(\mathrm{~F}=200.44_{04,20}, \mathrm{H}-\mathrm{F}-\mathrm{L}\right.$ adjusted $\left.\mathrm{p}=<0.0001\right)$; and estimated mass ( $\mathrm{F}=105.07_{04,20}$, H-F-L adjusted $\left.\mathrm{p}=<0.0001\right)$ (Table 2). Time for the 2009 growth data, was significant for peat for: plant height $\left(\mathrm{F}=06.81_{04,20}, \mathrm{H}-\mathrm{F}-\mathrm{L}\right.$ adjusted $\left.\mathrm{p}=0.0378\right)$ (Table 2).

For peat, consistently significant results for growth through time between years were seen for longest and typical axial shoot lengths, axial and lateral shoot numbers up to $5 \mathrm{~cm}$ above the soil surface, lamina length not including petiole length, lamina width, herbivory coded 0-1 and estimated mass.

Time for the 2008 growth data, was highly significant for steer manure for: plant height $\left(\mathrm{F}=42.69_{06,30}, \mathrm{H}-\mathrm{F}-\mathrm{L}\right.$ adjusted $\mathrm{p}=<0.0001)$; typical axial shoot length $\left(\mathrm{F}=29.63_{03,15}, \mathrm{H}-\mathrm{F}-\mathrm{L}\right.$ adjusted $\mathrm{p}=<0.0001$ ); internodes per longest axial shoot ( $\mathrm{F}$ $=28.68_{04.20}$, H-F-L adjusted $\left.\mathrm{p}=<0.0001\right)$; and estimated mass $\left(\mathrm{F}=49.24_{06,30}\right.$, H-F-L adjusted $\left.\mathrm{p}=<0.0001\right)($ Table 1$)$. Time for the 2008 growth data, was significant for steer manure for: longest axial shoot length $\left(\mathrm{F}=44.89_{04,20}, \mathrm{H}-\mathrm{F}-\mathrm{L}\right.$ adjusted $\mathrm{p}=$ 0.0002); axial and lateral shoot number $\left(\mathrm{F}=10.23_{03.15}, \mathrm{H}-\mathrm{F}-\mathrm{L}\right.$ adjusted $\mathrm{p}=0.0025)$; lamina length $\left(\mathrm{F}=04.94_{06,24}, \mathrm{H}-\mathrm{F}-\mathrm{L}\right.$ adjusted $\mathrm{p}=0.0023)$; lamina width $\left(\mathrm{F}=05.66_{06,24}, \mathrm{H}-\mathrm{F}-\mathrm{L}\right.$ adjusted $\mathrm{p}=0.0091)$; lamina width over lamina with petiole length $(\mathrm{F}=$ $06.03_{06,24}, \mathrm{H}-\mathrm{F}-\mathrm{L}$ adjusted $\left.\mathrm{p}=0.0022\right)$; and herbivory coded 0,1 $\left(\mathrm{F}=05^{9} .7_{06,12}, \mathrm{H}-\mathrm{F}-\mathrm{L}\right.$ adjusted $\left.\mathrm{p}=0.0301\right)($ Table 1$)$.

Time for the 2009 growth data, was highly significant for steer manure for: longest axial shoot length $\left(\mathrm{F}=35.54_{04,20}\right.$, H-F-L adjusted $\mathrm{p}=<0.0001)$; typical axial shoot length ( $\mathrm{F}=$ $49.04_{04,20}$, H-F-L adjusted $\mathrm{p}=<0.0001$ ); lamina with petiole length $\left(\mathrm{F}=11.72_{04,22}, \mathrm{H}-\mathrm{F}-\mathrm{L}\right.$ adjusted $\left.\mathrm{p}=0.0006\right)$; lamina width $\left(\mathrm{F}=13.58_{04,20}, \mathrm{H}-\mathrm{F}-\mathrm{L}\right.$ adjusted $\left.\mathrm{p}=<0.0001\right)$; herbivory coded both $0,1\left(\mathrm{~F}=63.12_{04,20}, \mathrm{H}-\mathrm{F}-\mathrm{L}\right.$ adjusted $\left.\mathrm{p}=<0.0001\right)$ and $0-4(\mathrm{~F}=$ $157.37_{04,20}, \mathrm{H}-\mathrm{F}-\mathrm{L}$ adjusted $\left.\mathrm{p}=<0.0001\right)$; and estimated mass $(\mathrm{F}=$ $35.76_{04,20}$, H-F-L adjusted $\mathrm{p}=<0.0001$ ) (Table 2; Figure 3). Time for the 2009 growth data, was significant for steer manure for plant height $\left(\mathrm{F}=05.63_{04,20}, \mathrm{H}-\mathrm{F}-\mathrm{L}\right.$ adjusted $\left.\mathrm{p}=<0.0452\right)$, axial and lateral shoot number $\left(\mathrm{F}=53.62_{04,20}, \mathrm{H}-\mathrm{F}-\mathrm{L}\right.$ adjusted $\left.\mathrm{p}=<0.0002\right)$ and lamina length $\left(\mathrm{F}=15.22_{04,20}, \mathrm{H}-\mathrm{F}-\mathrm{L}\right.$ adjusted $\left.\mathrm{p}=<0.0006\right)$ (Table 2).

For steer manure, consistently significant results for growth through time between years were seen for plant height, longest and typical axial shoot length, axial and lateral shoot numbers up to $5 \mathrm{~cm}$ above the soil surface, herbivory coded 0,1 , length not including petiole length, lamina width, and estimated mass (Figure 3). Lamina length excluding petiole length was more consistently significant than lamina length with the petiole length included.

Time for the 2008 growth data, was highly significant for terrace for: plant height $\left(\mathrm{F}=25.48_{06,36}, \mathrm{H}-\mathrm{F}-\mathrm{L}\right.$ adjusted $\left.\mathrm{p}=<0.0001\right)$; typical axial shoot length $\left(\mathrm{F}=24.69_{03,18}, \mathrm{H}-\mathrm{F}-\mathrm{L}\right.$ adjusted $\left.\mathrm{p}=<0.0001\right)$; internodes per longest axial shoot $\left(\mathrm{F}=34.73_{04,24}, \mathrm{H}-\mathrm{F}-\mathrm{L}\right.$ adjusted $\mathrm{p}$ $=<0.0001)$; and estimated mass $\left(\mathrm{F}=20.92_{06.36}, \mathrm{H}-\mathrm{F}-\mathrm{L}\right.$ adjusted $\mathrm{p}=$ $<0.0001$ ) (Table 1). Time for the 2008 growth data, was significant for terrace for: longest axial shoot length $\left(\mathrm{F}=40.57_{04,24}, \mathrm{H}-\mathrm{F}-\mathrm{L}\right.$ adjusted $\mathrm{p}=0.0002)$; axial and lateral shoot number $\left(\mathrm{F}=17.10_{03,18}\right.$, H-F-L adjusted $\mathrm{p}=0.0002)$; lamina length $\left(\mathrm{F}=04.46_{06,30}, \mathrm{H}-\mathrm{F}-\mathrm{L}\right.$ adjusted $\mathrm{p}=0.0024)$; lamina width $\left(\mathrm{F}=06.58_{06,30}, \mathrm{H}-\mathrm{F}-\mathrm{L}\right.$ adjusted $\mathrm{p}=0.0014)$; lamina width over lamina with petiole length $(\mathrm{F}=$ $06.16_{06,30}, \mathrm{H}-\mathrm{F}-\mathrm{L}$ adjusted $\left.\mathrm{p}=0.0025\right)$; lamina with petiole length over lamina width $\left(\mathrm{F}=04.13_{06,30}, \mathrm{H}-\mathrm{F}-\mathrm{L}\right.$ adjusted $\left.\mathrm{p}=0.0171\right)$; and herbivory coded $0,1\left(\mathrm{~F}=13.75_{06,18}\right.$, H-F-L adjusted $\left.\mathrm{p}=0.0005\right)$ (Table 1).

Time for the 2009 growth data, was highly significant for terrace for steer manure for: longest axial shoot length $\left(\mathrm{F}=33.61_{04,24}\right.$, H-F-L adjusted $\mathrm{p}=<0.0001)$; typical axial shoot length ( $\mathrm{F}=$ $35.10_{04,24}, \mathrm{H}-\mathrm{F}-\mathrm{L}$ adjusted $\left.\mathrm{p}=<0.0001\right)$; axial and lateral shoot number $\left(\mathrm{F}=62.60_{04,24}, \mathrm{H}-\mathrm{F}-\mathrm{L}\right.$ adjusted $\left.\mathrm{p}=<0.0001\right)$; lamina length $\left(\mathrm{F}=12.13_{04.24}\right.$, H-F-L adjusted $\left.\mathrm{p}=<0.0001\right)$; lamina with petiole length $\left(\mathrm{F}=11.15_{04.24}, \mathrm{H}-\mathrm{F}-\mathrm{L}\right.$ adjusted $\left.\mathrm{p}=<0.0001\right)$; lamina width $\left(\mathrm{F}=13.21_{04,24}, \mathrm{H}-\mathrm{F}-\mathrm{L}\right.$ adjusted $\left.\mathrm{p}=<0.0001\right)$; and herbivory coded both 0, $1\left(\mathrm{~F}=75.11_{04,24}, \mathrm{H}-\mathrm{F}-\mathrm{L}\right.$ adjusted $\left.\mathrm{p}=<0.0001\right)$ and 0-4 (F $=273.24_{04,24}, \mathrm{H}-\mathrm{F}-\mathrm{L}$ adjusted $\left.\mathrm{p}=<0.0001\right)$ (Table 2). Time for the 2009 growth data was significant for terrace for estimated mass ( $\mathrm{F}$ $=08.83_{04,24}, \mathrm{H}-\mathrm{F}-\mathrm{L}$ adjusted $\left.\mathrm{p}=0.0190\right)($ Table 2$)$.

For terrace, consistently significant results for growth through time between years were seen for longest and typical axial shoot length, axial and lateral shoot number up to $5 \mathrm{~cm}$ above the soil surface, lamina length without the petiole, lamina width, and herbivory coded 0,1 . Time for the 2008 growth data for terrace was unusual for steer manure in that estimated mass was not significant.

For all four of the independent measured variables, consistently significant results for growth through time between years was only seen for longest and typical axial shoot length, axial and lateral shoot numbers counted on stems up to $5 \mathrm{~cm}$ above the soil surface, lamina length not including petiole length and lamina width. Each of these characters has both benefits and issues that might 
limit their usefulness. Axial shoot measurements and counts required handling of and/or stretching out of increasingly viney stems. As the season progressed, vines became more rigid and handling them often resulted in breakage, potentially throwing off subsequent measurement of length or shoot numbers. Counting shoots in the overlapping vines within $5 \mathrm{~cm}$ of the soil surface became difficult as well, as the vines obscured each other, or worse became entangled, with rearrangement risking more breakage.' on above and below lines. Therefore, those characters are best used only in the first few weeks of growth, and at harvest. Lamina length and width characters appear very useful. However, they may have little meaning individually or relative to plants at other sites, as leaves of both varieties appear capable of continuous growth, interspersed with plateaus which falsely appeared to be the maximum possible or typical size. Several times we thought we knew the top of the range of leaf sizes for the plant, yet under different lighting or fertilizer conditions in the greenhouse, leaves would suddenly begin to grow again, exhibiting dramatic gains in size. Some of these sudden and dramatic increases in leaf size only occurred after several years of consistent maximum leaf growth by an individual plant or group of plants in the greenhouse. Also, new leaves are constantly emerging all season along the multiple vines that form the crop's adult habit. For these reasons, leaves typical in size for a plot were measured.

The next best character for tracking growth through time was estimated mass, which only lacked significance for terrace and only in 2008. Estimated mass is often used as a measurement to track growth in agricultural studies. However, estimated mass can be a highly subjective measurement. Even if individual researchers are consistent in how they measure estimated mass, other researchers may differ somewhat in method, making comparison between data sets from different workers less reliable for this character. Though the herbivory coded 0,1 character also gave positive results through time, it did not clearly show a pattern that correlated with the levels of soil amendments. In addition, herbivory coded 0,1 did not give positive results for COA, even though it did so both years for peat and steer manure separately, as well as for terrace. Monitoring herbivory was most useful for paying attention to what fed on the plants. Several species of caterpillars voraciously consumed leaves, including hawk moth caterpillars which often clung tightly to $M$. expansa vines, resisting removal by hand.

Interaction of Time with Independent Variables: Interaction of time with COA for the 2008 growth data was significant for plant height $\left(\mathrm{F}=05.64_{18,24}, \mathrm{H}-\mathrm{F}-\mathrm{L}\right.$ adjusted $\left.\mathrm{p}=0.0110\right)$ and estimated mass $\left(\mathrm{F}=04.74_{18,24}, \mathrm{H}-\mathrm{F}-\mathrm{L}\right.$ adjusted $\left.\mathrm{p}=0.0151\right)$ (Table 1). Interaction of time with steer manure for the 2008 growth data was only significant and only for estimated mass $\left(\mathrm{F}=04.38_{12,30}, \mathrm{H}-\mathrm{F}-\mathrm{L}\right.$ adjusted $\left.\mathrm{p}=0.0230\right)$. Interaction of time with peat and with terrace for the 2008 growth data each had no significance (Table 1).

Interaction of time with COA for the 2009 growth data was only highly significant for estimated mass $\left(\mathrm{F}=21.16_{12,16}, \mathrm{H}-\mathrm{F}-\mathrm{L}\right.$ adjusted $p=0.0001$ ) (Table 2). Interaction of time with COA for the 2009 growth data was significant for typical axial shoot length $(\mathrm{F}=04.7512,16, \mathrm{H}-\mathrm{F}-\mathrm{L}$ adjusted $\mathrm{p}=0.0023)$, axial and lateral shoot number $\left(\mathrm{F}=05.61_{12,16}, \mathrm{H}-\mathrm{F}-\mathrm{L}\right.$ adjusted $\left.\mathrm{p}=0.0095\right)$ and lamina length $\left(\mathrm{F}=03.53_{12,16}\right.$, H-F-L adjusted $\left.\mathrm{p}=0.0102\right)$ (Table 2).

Interaction of time with peat for the 2009 growth data was also highly significant only for estimated mass $\left(\mathrm{F}=24.46_{08,20}\right.$, H-F-L adjusted $p=<.0001$ ) (Table 2). Interaction of time with peat for the 2009 growth data was significant for axial and lateral shoot number $\left(\mathrm{F}=05.30_{0820}, \mathrm{H}-\mathrm{F}-\mathrm{L}\right.$ adjusted $\left.\mathrm{p}=0.0222\right)$, lamina length $\left(\mathrm{F}=04.02_{08,20}, \mathrm{H}-\mathrm{F}-\mathrm{L}\right.$ adjusted $\left.\mathrm{p}=0.0055\right)$ and lamina with petiole length $\left(\mathrm{F}=02.76_{08,20}, \mathrm{H}-\mathrm{F}-\mathrm{L}\right.$ adjusted $\mathrm{p}=$ 0.0355) (Table 2).

Interaction of time with steer manure growth data was only significant for estimated mass, for both $2008\left(\mathrm{~F}=04.38_{12,30}\right.$, H-F-L adjusted $\mathrm{p}=0.0230)$ (Table 1) and $2009\left(\mathrm{~F}=08.22_{8,20}\right.$, H-F-L adjusted $\mathrm{p}=0.0023$ ) (Table 2).

Interaction of time with $\mathrm{COA}$, and with steer manure, were only consistently significant for both years for estimated mass. Interaction of time with peat was not consistently significant for estimated mass for both years, nor for any measured character. Interaction of time with terrace had no significant characters either year (Tables 1 and 2).

Individual growth characters for $M$. expansa were more meaningful when analyzed through time than when examined in the ANOVA results for treatment, or in the interactions between time and the independent variables.

\section{Resolution of the General Question and Two Hypotheses}

For the general question on growing $M$. expansa across the growing season, the expectation of failure was not met. For the hypothesis on the peat application at the time of construction influencing growth, the null of no effect was rejected. Peat in 2008 had a slightly significant effect on herbivory, also a high significance for the interaction of peat with time for herbivory, and slight significance for the interaction of peat with time for the ratio of lamina width over the length of the lamina with the petiole included. Peat in 2009 was slightly significant for the interaction of peat with time for both typical axial shoot length and axial shoot number. For estimated mass, peat and peat's interaction with time were highly significant in 2009. Lamina length somewhat, and lamina with petiole length slightly, were significant for the interaction of peat with time for var. ' $L$ ' in 2009.

For the hypothesis that the original steer manure application had an effect on the growth of var. ' $L$ ' in the sand plots, the null of no effect was again rejected. The same outcome was seen for COA, though there was no COA hypothesis. Steer manure's interaction with time for estimated mass in 2008, had a slightly significant effect on plant height and a highly significant interaction with time. Steer manure in 2009 had a slightly significant effect on estimated mass, and a highly significant effect on the interaction of estimated mass with time.

Although no hypothesis was written for COA, that data was also analyzed. COA includes var. ' $L$ ' data from all plots containing only peat, or only steer manure, as well as from the 1P3S plots. COA in 2008 was slightly significant for plant height and extremely highly significant for its interaction with 
time on plant height for var. ' $L$ '. COA interaction with time in 2009 was also somewhat significant for longest axial shoot length. COA interaction with time was highly significant for estimated mass in 2009. COA in 2009 was somewhat significant for lamina with petiole length.

\section{Conclusions and Recommendations}

Varieties ' $L$ ' and ' $T$ ' of $M$. expansa were shown to have grown in the northern temperate climate of southern Illinois even in very wet years. Insight was also gleaned from our observations while growing the plants indoors and in the greenhouse, into plant requirements and differences between the ways the two varieties grow. Some significant differences were seen for the impact of the original soil treatments, though there were inconsistencies between years, and within and among levels of soil amendment, for different measured characters.

Harvest data allowed for comparison of the two varieties for weight gain. Harvest data also gave information on wet-to-dry ratios above and below ground for each variety in 2009, and between 2008 and 2009 for var. ' $L$ '. Harvest data indicated that var. ' $L$ ' had larger roots than var. ' $T$ '. However, var. ' $L$ ' roots contained a higher percentage of water than those of var. ' $T$ '.

Additional differences between the two varieties were in sensitivity to moisture, as well as the size of plants early in the season. The volume of above-ground portions of var. ' $T$ ' appeared to have caught up with var. ' $L$ ' towards the end of 2009. Var. ' $L$ ' seemed more tolerant to wet southern Illinois conditions and produced more forage from early through mid-season, than var. ' $T$ '. Var. ' $T$ ' seems to be more drought tolerant than var. ' $L$ '. These considerations concerning drought and flooding tolerance are based on multiple observations in both field and greenhouse, which varied in degree each year. In addition, by harvest time both years for var. ' $L$ ', fresh whole plant weights were several times heavier for the upper terrace over the middle terrace, in all-sand control plots. This resulted in very large SDs in graphs of both growth and harvest data for var. ' $L$ ' controls (Figures 4 and 5, Supplementary Figure 4).

Clones of each variety survived about ten years from the time they were first planted in the greenhouse in southern Illinois. This was in a less than hospitable climate for the crop, due to combined extreme heat and humidity in the summers (Angel, 2008, 2009, 2010a, 2010b; Carbondale Illinois Airport/ NOAA, 2008, 2009, 2010; Changnon and Black, 2009; Daily Republican, 2011; Kritzer Van Zant, 2016a Appendices B-2, B-3 and B-6). Long survival times for serially grown clones are promising for several areas of long term research with the crop. This ability of $M$. expansa, to be clonally propagated in the field or greenhouse for extended periods, is similar to the ability of some cell types to withstand being passed to fresh media for generations, in that longevity and continuity are valuable traits for any model organism.

$M$. expansa has a high possibility for being reclaimed as a highly valuable crop. This is especially true as the search intensifies for solutions to the impact of climate change upon agriculture. Funding is required to help this to happen.

Four recommendations are given, which address the usefulness of $M$. expansa as a modern agricultural crop.

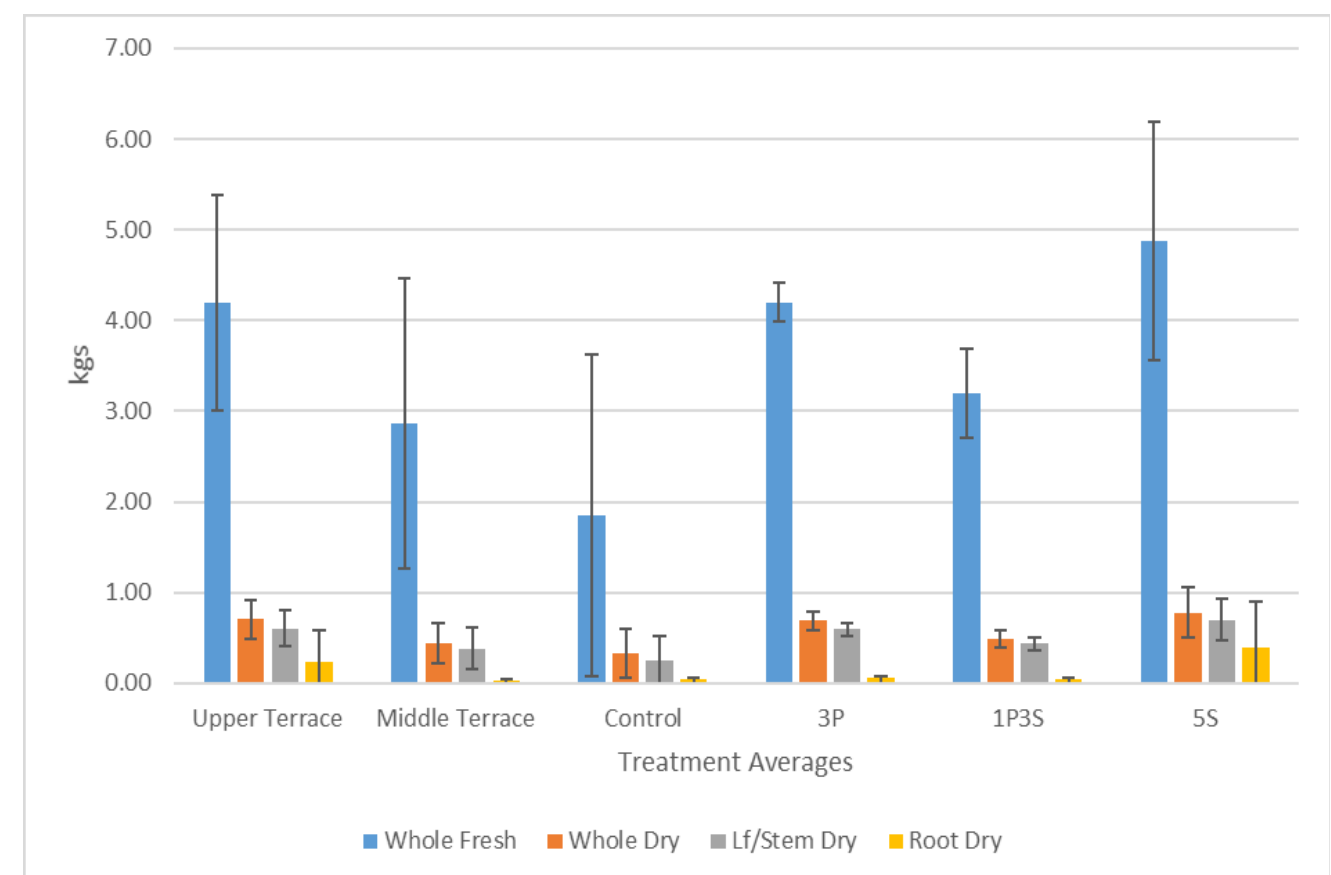

Figure 4. Chart of 2008 var. 'L' Harvest Weights Fresh \& >30 Days Dry with SDs, grown in outdoor sand plots. X-axis: Treatments: Upper Terrace and Middle Terrace, Soil Amended plot types 5S, 3P, 1P3S and Control. y-axis: Weights in kgs. Abbreviations: 5S, 5\% steer manure; 3P, 3\% peat; $1 \mathrm{P} 3 \mathrm{~S}$, combined organic amendments 1\% peat and 3\% steer manure; Control was all sand. 


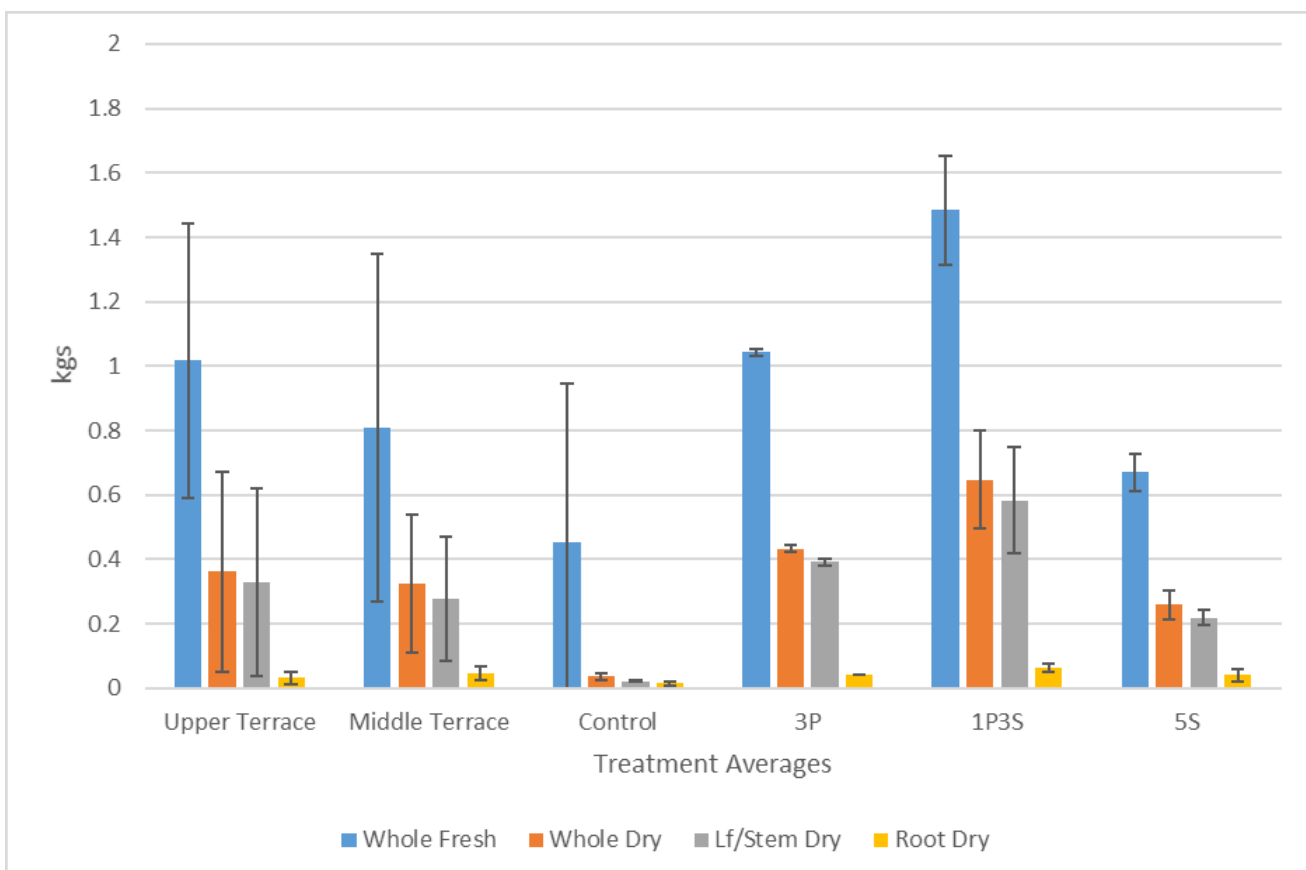

Figure 5. Chart of 2009 var. 'L'Harvest Weights Fresh \& Nine Days Dry with SDs, grown in outdoor sand plots. X-axis: Treatments: Upper Terrace and Middle Terrace, Soil Amended plot types Control, 3P, 1P3S and 5S. y-axis: Weights in kgs. Abbreviations: Control was all sand; 3P, 3\% peat; 1P3S, combined organic amendments $1 \%$ peat and $3 \%$ steer manure; $5 \mathrm{~S}, 5 \%$ steer manure.

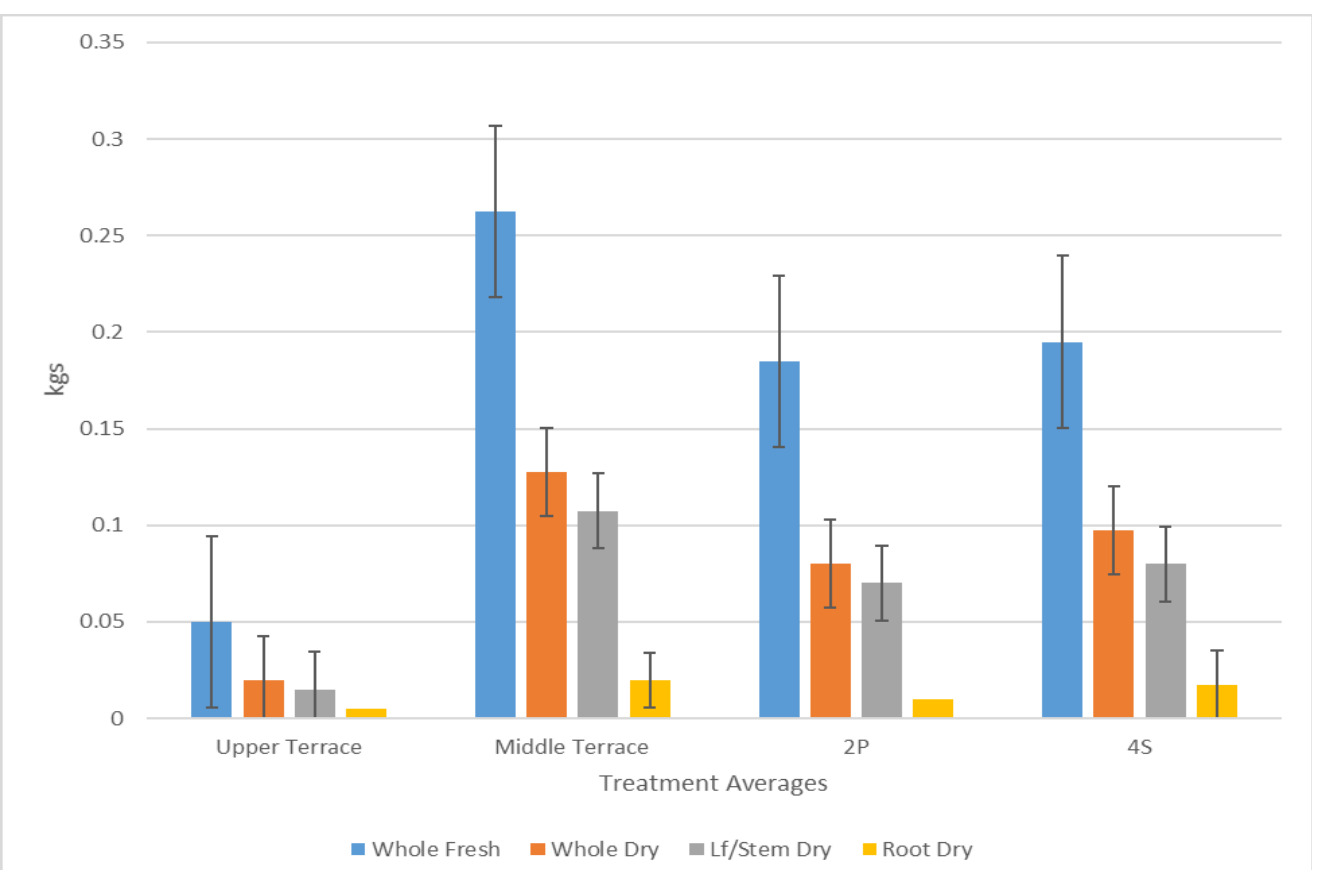

Figure 6. Chart of 2009 var. ' $T$ ' Harvest Weights Fresh \& Nine Days Dry with SDs, grown in outdoor sand plots. X-axis: Treatments: Upper Terrace and Middle Terrace, Soil Amended plot types 2P, 2\% peat; 4S, 4\% steer manure. y-axis: Weights in kgs. 
First, more experiments are needed on a larger scale to address best methods for growing $M$. expansa. These experiments should additionally give a clearer picture of which growth characteristics should be measured to track growth in the crop. Second, research on the crop's complex genetics, epigenetics and possible ploidy issues should be funded. Genetic research may add to the crop's economic value. Mirabilis can provide a fresh window into real time variation in expression on individuals, that is highly localized, and ongoing during the life of the plant. Third, nutrition and food-safety research should be funded for use of both $M$. expansa roots for human food, and the leaves and stems for forage and dry feed. The plant is an excellent source of large amounts of amino acids, including all essential amino acids. The roots and enlarged rhizomes also contain large amounts of minute starch grains. Though we will present currently completed research on these topics in future papers, additional investigation is needed. Fourth, there are likely better places in North America and elsewhere to grow M. expansa than in southern Illinois. Areas with sandy and volcanic soils are probably best suited, though these results indicate soils can also be modified for these plants. Anywhere the crop can obtain water through stems and leaves above ground or through rhizomes below ground, while the root zone remains dry, has potential for growing the crop. M. expansa is highly endangered, as well as highly nutritious and drought resistant. The crop should be grown at more sites as soon as possible, with monitoring to make sure it does not become invasive in specific ecosystems. $M$. expansa's extreme sensitivity to standing water in soils, makes it unlikely to become widely, permanently, invasive in the United States.

\section{Conflict of Interest}

The authors do not have and do not declare any conflict of interests for the research in this paper.

\section{Acknowledgements}

The following individuals and institutions are thanked by the authors for their assistance: S.K. Chong; Brian Klubek; John Miller; John Preece; Tod D. Swanson; Abraham Kritzer; Judy Robins; Andes and Amazon Field School and Center for Latin American Studies at Arizona State University; Centro Internacional de la Papa (CIP); Herbario Nacional Quito (QCNE); Horticulture Research Center-SIU-C; and the United States Department of Education. S.K. Chong originally built the sand plots. John Preece, Brian Klubek and Ken Diesburg gave advice on what field characters to measure. Diesburg also gave permission for Kritzer Van Zant to use the sand plots. John Miller and John Preece gave advice on growing $M$. expansa in the greenhouse. Rich Cole was first to try growing M. expansa from cuttings on a mist bench at SIU. John D. Reeve and David Lightfoot gave advice on the statistical treatments. The Lightfoot lab paid for testing of soil samples for their nitrogen content. Tod D. Swanson, the Arizona State University Field School in Ecuador, as well as a United States Department of Education fellowship, made it possible for Kritzer Van Zant to travel to Ecuador to attend Kichwa, taxonomy and ethnobotany classes, the jumping off point for the research which led to finding var. ' $T$ '. There was no conflict of interest created by that funding. Rhizomes were deposited in Ecuador and later sent under agreement to SIU-C. A set of voucher herbarium specimens for the var. ' $T$ ' plants, collected in the field in Ecuador, were deposited at QCNE [KVZant \#s 318, 319, and 320]. Variety ' $L$ ' seed was sent to Kritzer Van Zant from Centro Internacional de la Papa in Lima, Peru. Herbario Nacional in Quito, Equador was Kritzer Van Zant's host institution for collecting M. expansa var. 'T' samples. Brigida Guachuiun and Lewis Enrique Puente transported Kritzer Van Zant to their property to introduce her to Eloisa de la Cruz, who grew the crop.

\section{References}

Angel J (2008, 2009, 2010a) Illinois State Water Survey Climate division data (division 8). Prairie Research Institute University of Illinois Champaign-Urbana. downloaded 31 Mar 2013 no longer available from: http://mrcc.isws.illinois.edu/state_climatologists/illinois/clidiv/il_cli_div2.jsp; downloaded 2 Jan 2017 from: http://www.isws.illinois.edu/warm/dataarchive.asp, select month and year, then Carbondale.

Angel J (2010b) Illinois State Water Survey Climate events of 2009 in Illinois. Prairie Research Institute University of Illinois Champaign-Urbana. downloaded 31 Mar 2017 from: http://www.isws. illinois.edu/atmos/statecli/events2009.htm.

Camino A (1992) Chapter 22 Andean farming systems: farmer's strategies and responses. In: NS Jodha, M Banskota, T Partap (eds.) Sustainable Mountain Development; Farmer's Strategies and Innovative Approaches Volume II. Oxford \& IBH Publishing Co. Pvt. Ltd., New Delhi, India, pp. 517-537.

Carbondale Illinois Airport/NOAA (2008, 2009, 2010) Quality controlled local climatological data for October. downloaded $31 \mathrm{Mar}$ 2013 from: http://cdo.ncdc.noaa.gov/qclcd/QCLCD?prior=N\&sta te $=$ IL\&wban $=93810$.

Changnon SA and A Black (2009) Illinois State Water Survey 2008 a record wet and stormy year in Illinois. Institute of Natural Resource Sustainability University of Illinois at Urbana-Champaign ISWS/RI-117/2009 Report of Investigation 117.21. downloaded 31 Mar 2013 from: http://www.isws.illinois.edu/pubdoc/RI/ ISWSRI-117.pdf.

Coe F (2016) Calcium binding by citrate. University of Chicago Kidney Stone Evaluation and Treatment Program downloaded 2 Jan 2016 from: http://kidneystones.uchicago.edu/calcium-bindingby-citrate/.

Conway GR (1992) Preface. In: NS Jodha, M Banskota, T. Partap (eds.) Sustainable Mountain Development; Farmer's Strategies and Innovative Approaches Volume II, Oxford \& IBH Publishing Co. Pvt. Ltd., New Delhi, India, pp. ix-x.

Daily Republican, The (2011) Southern Illinois counties declared disaster areas due to 2010 Drought. downloaded 31 Mar 2013 from: http://www.dailyrepublicannews.com/article/20110127/ NEWS/301279805.

Di Falco S, and C Perrings (2005) Crop biodiversity, risk management and the implications of agricultural assistance. Ecol Econ 55 (4): 459-466.

Evenson RE, and D Gollin (2003) Assessing the impact of the Green Revolution, 1960 to 2000. Science 300 (5620): 758-762, 2003. 
Fjeldså J, MD Alvarez, JM Lazcano, and B Leon (2005) Illicit crops and armed conflict as constraints on biodiversity conservation in the Andes region. AMBIO 34 (3): 205-211.

Korth KL, SJ Doege, SH Park, FL Goggin, Q Wang, SK Gomez, G Liu, L Jia, and PA Nakata (2006) Medicago truncatula mutants demonstrate the role of plant calcium oxalate crystals as an effective defense against chewing insects. Plant Physiol 41(1):188-195.

Kritzer Van Zant M (2016a) Analysis and Development of Mirabilis expansa (Ruiz and Pav.) Standl.; For Potential as a New Root Crop Outside the Andes (Doctoral Dissertation). ProQuest Dissertations and Theses. (Accession Order No. 12694).

Kritzer Van Zant M (2016b) History of Mirabilis expansa (Ruiz and Pav.) Standl.; Growth and use in the Andes. Atlas J Bio doi: 10.5147, 236-248. downloaded 31 May 2016 from: http://journals. atlas-publishing.org/index.php/AJB/article/view/35/34.pdf.

Kritzer Van Zant M (2016c) Review of the economic and ethno-botany of the family Nyctaginaceae. Atlas J Bio doi: 10.5147, 267-273. downloaded 31 May 2016 from: http://journals.atlas-publishing. org/index.php/AJB/article/view/36/35.pdf.

Massey LK, H Roman-Smith, and RA Sutton (1993) Effect of dietary oxalate and calcium on urinary oxalate and risk of formation of calcium oxalate kidney stones. J Am Diet Assoc 93 (8): 901-906.

Olsen N (2004) Seed Potato Performance. University of Idaho, USDA Research, Education \& Economics Information System. downloaded 22 Feb 2016, no longer available from: http://www.reeis. usda.gov/web/crisprojectpages/0183486-seed-potato-performance. html. downloaded 2 Jan 2017 from: http://portal.nifa.usda.gov/ web/crisprojectpages/0183486-seed-potato-performance.html.

Partap T (1992) Chapter 12 Biological diversity in sustainable development of mountain Agriculture. In: NS Jodha, M Banskota, and T Partap (eds.) Sustainable Mountain Development; Perspectives and Issues Volume I. Oxford \& IBH Publishing Co. Pvt. Ltd., New Delhi, India, pp. 273-304.

Perry A (2012) A Rough, Tough Forage for Range Land Cattle. USDA AgRes Mag. downloaded 22 Feb 2016 from: http://agresearchmag. ars.usda.gov/2012/jan/cattle.

Popenoe H, SR King, J León, and LS Kalinowski (1989) Mauka. In: ND Vietmeyer (ed) Lost Crops of the Incas; Little-Known Plants of the Andes with Promise for Worldwide Cultivation. Natl. Academy Press, Washington, D.C., pp. 74-81. downloaded 24 Jan 2012, no longer available from: http://www.nap.edu/ openbook/030904264X/html/'74,html. downloaded 29 Feb 2012 from: www.nap.edu/openbook.php?record_id=1398\&page $=74$.

Putnam DH, CG Summers, and SB Orloff (2007) Alfalfa production systems in California. In: CG Summers, DH Putnam (eds.) Irrigated Alfalfa Management for Mediterranean and Desert Zones; Chapter 1. U of CA Agriculture and Natural Resources. Publication 8287, Oakland, CA., 19 Pp. downloaded 22 Feb 2016 from: http:// alfalfa.ucdavis.edu/IrrigatedAlfalfa/pdfs/UCAlfalfa8287ProdSystems_free.pdf.

Ranganathan N, P Ranganathan, EA Friedman, A Joseph, B Delano, DS Goldfarb, P Tam, A Venketeshwer, AV Rao, E Anteyi, and CG Musso (2010) Pilot Study of probiotic dietary supplementation for promoting healthy kidney function in patients with chronic kidney disease. Adv Ther 27(9):634-647. downloaded 17 Aug 2015 from: http://www.academia.edu/2108877/Pilot_Study_of_Probiotic_Di-
etary_Supplementation for Promoting Healthy Kidney Function in_Patients_with_Chronic_Kidney_Disease.

Rea J (1992) Andean roots. In: JE Hernández-Bermejo, J León (eds.) Neglected Crops: 1492 from a Different Perspective. Botanical Garden of Córdoba, Andalusia, Spain. downloaded 17 Jan 2001 from: http://www.hort.purdue.edu/newcrop/1492notes.html.

FAO-UN, Rome (1994). downloaded 24 Jan 2012 from: www.fao.og/ docrep/T0646E00/htm.

Seminario Cunya J (1993) Aspectos etnobotanicos y morfologicos del chago, miso o mauka (Mirabilis expansa R. y P.) en el Peru. B Lima 15 (86): 71-79.

Seminario Cunya J (2000) Fascículo 27 Aspectos etnobotanicos y productivos del chago, miso o mauka, Mirabilis expansa (Ruízy Pavón) Standley. In: J Seminario Cunya (ed) Raíces Andinas Manual de Capacitation. Centro Internacional de la Papa (CIP), Lima, Peru, pp. 1-9.

Seminario Cunya J (2004) 26 Aspectos etnobotanicos y productivos del chago, miso o mauka (Mirabilis expansa [Ruíz y Pavón] Standley). In: J Seminario Cunya (ed) Raíces Andinas: Contribuciones al conocimiento y a la capacitation; Serie: Conservación y uso de la biodiversidad de raíces y tubérculos Andinos: Una década de investigación para el desarrollo (1993-2003) No. 6. Universidad Nacional de Cajamarca, Centro Internacional de la Papa (CIP), Agencia Suiza para el Desarrollo y la Cooperación, Lima, Perú, pp. 367-376.

Tapia ME (1992) Chapter 4. Mountain agricultural development strategies: The Andean Perspective. In: NS Jodha, M Banskota, T Partap (eds.) Volume 1 Part 1: Agriculture Development in Mountain Areas: Perspectives and Approaches. International Centre for Integrated Mountain Development (ICIMOD), Kathmandu, Oxford \& IBH Publishing Co., PVT. LTD, New Delhi, Bombay, and Calcutta, India, pp. 115-128.

Thanyasiriwat T, S Sraphet, S Whankaew, O Boonseng, J Bao, DA Lightfoot, S Tangphatsornruang, and K Triwitayakorn (2013) Quantitative trait loci and candidate genes associated with starch pasting viscosity characteristics in cassava (Manihot esculenta Crantz). Plant Biol (Stuttgart) doi: 10.111116/plb.12022, 197-207.

Turroni S, SB Vitali, C Bendazzoli, M Candela, R Gotti, F Federici, F Pirovano, and P Brigidi (2007) Oxalate consumption by Lactobacilli: Evaluation of oxalyl-CoA decarboxylase and Formyl-CoA transferase activity in Lactobacillus acidophilus. J Appl Microbiol 103(5):1600-9. downloaded 17 Aug 2015 from: http:/www.ncbi. nlm.nih.gov/pubmed/17953571.

Turroni S, SC Bendazzoli, SCF Dipalo, M Candela, B Vitali, R Gotti, and P Brigidi (2010) Oxalate-degrading activity in Bifidobacterium animalis subsp. lactis: Impact of acidic conditions on the transcriptional levels of the oxalyl coenzyme A (CoA) decarboxylase and formyl-CoA transferase genes. Appl Environ Microb 76(16):56095620. downloaded abstract 17 Aug 2015 from: http://www.ncbi. nlm.nih.gov/pmc/articles/PMC2918965/.

Vepachedu R, HP Bais, and JM Vivanco (2003) Molecular characterization and post-transcriptional regulation of ME1, a type I ribosome-inactivating protein from Mirabilis expansa. Planta 217 (3): 498-506.

Zimmerer KS (1992) The loss and maintenance of native crops in mountain agriculture. GeoJ 27 (1): 61-72. 


\section{Summary of Supplementary Materials}

Supplementary Material includes a description of the appearance of $M$. expansa varieties ' $L$ ' and ' $T$ ', details on how the crop was grown in the greenhouse, additional details on field plot conditions including precipitation, information on the lyophilization of harvested material for subsequent nutritional research, positive exploratory data that did not apply directly to hypotheses in this paper, consideration of patterns of negative data, and additional discussion including consideration of harvest data. Information included in the Supplementary Material may be useful to future growers of the crop.

\section{Description of M. expansa Crop Varieties}

Crop varieties of M. expansa appear as dense masses of fine vines, cascading outward more or less in a circle. This cascading appearance was less pronounced for both varieties in the short growing season of southern Illinois, in comparison with mature var. ' $T$ ' plants seen by Kritzer Van Zant in Ecuador. The wild type's mature habit is reported as bush-like, in type descriptions, regional keys, and in descriptions on herbarium sheets. Var. ' $L$ ' seed, var. ' $T$ ' rhizomes, and off-shoots from cuttings of both, in a greenhouse medium without extra fertilizer, emerged into a bush-like, branching habit. In the presence of additional fertilizer, new growth from greenhouse cuttings could emerge as a rosette, later developing the bush-like habit. Stems normally develop into vines as the crop matures. Both varieties ' $L$ ' and ' $T$ ' have ovate or nearly-ovate leaves, and are more stable for leaf shape than wild $M$. expansa, which frequently has varied leaf shapes. Variety ' $L$ ' usually exhibits dark green foliage and stems, red-purple veins, flowers, and leaf and stem splotches, and its turmeric-colored root epidermis has a slightly sparkling crystalline appearance, at harvest. Variety ' $T$ ' usually exhibits lighter green leaves and stems, with white or creamy light green veins, flowers, and leaf splotches, and a non-crystalline light tan-colored root epidermis. Roots of both varieties have light-colored starchy flesh internally. The relatively young age at harvest of southern Illinois field grown plants must be considered in matters of color. Each variety can temporarily mimic the other for leaf and stem coloration, especially in the earliest stages of growth, no matter the method of propagation. However, red leaf veins on young var. ' $T$ ' plants are usually not as deeply colored as those on var. ' $L$ ' plants, and in most cases, red-veined var. ' $T$ ' plants soon revert to having lighter colored veins as they continue growing.

M. expansa is unusual for having both enlarged storage roots and rhizomes. Root here refers to true root tissue, free of nodes. Rhizomes are enlarged underground stems and therefore have nodes. Once enlarged with starch, roots and rhizomes become indistinguishable in appearance, even in cross-section, particularly where they meet in the crown region of mature plants.
Var. ' $L$ ' always gained size more quickly and exhibited greater harvest weights than var. ' $T$ ' in the southern Illinois outdoor sand plots. Size differences between varieties were less obvious at all stages of growth in the greenhouse.

An extended description of $M$. expansa is in Kritzer Van Zant (2016a), along with information on crop distribution, greenhouse culturing, and cropping rationale for these plants.

\section{Additional information on growing M. expansa in the Field and Greenhouse}

Propagation in Greenhouses: Basic greenhouse media for maintaining stock of $M$. expansa consisted of equal amounts of perlite, vermiculite, and sand, plus $5-15 \%$ peat. Additions of $5-10 \%$ of the dense organic fertilizer vermifuge, increased moisture in the medium used to start cuttings. Vermifuge is denser than mushroom composted horse manure. This may be why it took a larger volume of mushroom composted horse manure to get the same level of moisture retention as from using a smaller volume of vermifuge. With addition of either fertilizer, it was necessary to remove plants from the mist within two weeks of starting them or they rotted away. Rotting usually occurred sooner for var. ' $T$ ' compared with var. ' $L$ '. Root remnants, usually disappeared overnight, when more mature plants became too wet in the greenhouse. It appeared that rapid rotting of roots led to plant death. Without using fertilizer, cuttings did not rot so easily but still did better if removed from the mist bench as soon as new leaf buds began to open.

Cuttings and Planting: Most stock plants were started from stem cuttings in a base of equal amounts of perlite, vermiculite, and sand, on a mist bench in the greenhouse, without heating pads. Once plants had a few weeks off the mist bench, they were transplanted with $15 \%\left(\mathrm{v}^{3} / \mathrm{v}^{3}\right)$ peat, added to equal amounts of perlite, vermiculite, and sand.

Cuttings intended for field planting were started on the mist bench on 26 Feb 2008, 10 Jan 2009, and 10 Apr 2009. The Jan 2009 cuttings were started in a mixture of $80 \% 1: 1: 1$ vermiculite: perlite: sand, with $20 \%\left(\mathrm{v}^{3} / \mathrm{v}^{3}\right)$ vermifuge [aka vermicompost], on the mist bench, without heating pads. Red worms (Eisenia fetida) fed food waste at the vermifuge center at SIU-C (http://coas.siu.edu/research/university-farms-forest-research/ sustainability-center/vermicomposting.html), were the source of the vermifuge.

For each batch of cuttings, once new leaves appeared, plants were transferred from the mist bench to a dry bench where they received two to three days of daily watering. After that they were watered infrequently, usually no more than twice a week.

In 2008, young var. ' $L$ ' plants grown from cuttings, were planted outdoors on 2 July and no replacements were made through the season. Var. 'T' plants were first planted outside in 2009. Both varieties were planted into the outdoor sand plots in 2009 . 
Supplementary Table 1. 2008 harvest data for var. ' $L$ ' with averages for controls, amendments, and terraces.

\begin{tabular}{llllllr}
\hline Terrace & Treatment & Whole wet & Whole dry & $\begin{array}{l}\text { Whole } \\
\text { Dry/fresh }\end{array}$ & $\begin{array}{l}\text { Lf/stem } \\
\text { dry }\end{array}$ & $\begin{array}{l}\text { Root } \\
\text { dry }\end{array}$ \\
\hline Terrace Avg & mid-all & $2.9 \mathrm{~kg}$ & $0.4 \mathrm{~kg}$ & $15.4 \%$ & $0.4 \mathrm{~kg}$ & $>0.1 \mathrm{~kg}$ \\
Terrace Avg & upr-all & $4.2 \mathrm{~kg}$ & $0.7 \mathrm{~kg}$ & $16.7 \%$ & $0.6 \mathrm{~kg}$ & $0.2 \mathrm{~kg}$ \\
Upr & Control & $3.1 \mathrm{~kg}$ & $0.5 \mathrm{~kg}$ & $16.8 \%$ & $0.4 \mathrm{~kg}$ & $0.1 \mathrm{~kg}$ \\
Mid & Control & $0.6 \mathrm{~kg}$ & $0.1 \mathrm{~kg}$ & $23.3 \%$ & $0.1 \mathrm{~kg}$ & $>0.1 \mathrm{~kg}$ \\
Treatment Avg & Control & $1.9 \mathrm{~kg}$ & $0.3 \mathrm{~kg}$ & $17.9 \%$ & $0.3 \mathrm{~kg}$ & $>0.01 \mathrm{~kg}$ \\
Upr & $3 \mathrm{P}$ & $4.4 \mathrm{~kg}$ & $0.8 \mathrm{~kg}$ & $17.5 \%$ & $0.7 \mathrm{~kg}$ & $0.1 \mathrm{~kg}$ \\
Mid & $3 \mathrm{P}$ & $4.1 \mathrm{~kg}$ & $0.6 \mathrm{~kg}$ & $15.3 \%$ & $0.6 \mathrm{~kg}$ & $0.1 \mathrm{~kg}$ \\
Treatment Avg & $3 \mathrm{P}$ & $4.2 \mathrm{~kg}$ & $0.7 \mathrm{~kg}$ & $16.4 \%$ & $0.6 \mathrm{~kg}$ & $0.1 \mathrm{~kg}$ \\
Upr & $1 \mathrm{P} 3 \mathrm{~S}$ & $3.6 \mathrm{~kg}$ & $0.6 \mathrm{~kg}$ & $15.8 \%$ & $0.5 \mathrm{~kg}$ & $0.2 \mathrm{~kg}$ \\
Mid & $1 \mathrm{P} 3 \mathrm{~S}$ & $2.9 \mathrm{~kg}$ & $0.4 \mathrm{~kg}$ & $15.1 \%$ & $0.4 \mathrm{~kg}$ & $<0.1 \mathrm{~kg}$ \\
Treatment Avg & 1P3S & $3.2 \mathrm{~kg}$ & $0.5 \mathrm{~kg}$ & $15.3 \%$ & $0.4 \mathrm{~kg}$ & $<0.1 \mathrm{~kg}$ \\
Upr & $5 \mathrm{~S}$ & $5.8 \mathrm{~kg}$ & $1.0 \mathrm{~kg}$ & $16.9 \%$ & $0.9 \mathrm{~kg}$ & $0.8 \mathrm{~kg}$ \\
Mid & $5 \mathrm{~S}$ & $4.0 \mathrm{~kg}$ & $0.6 \mathrm{~kg}$ & $14.7 \%$ & $0.5 \mathrm{~kg}$ & $<0.1 \mathrm{~kg}$ \\
Treatment Avg & $5 \mathrm{~S}$ & $4.9 \mathrm{~kg}$ & $0.8 \mathrm{~kg}$ & $16.0 \%$ & $0.7 \mathrm{~kg}$ & $0.4 \mathrm{~kg}$ \\
\hline
\end{tabular}

Notes: Averaged by treatment, 2 plants averaged, one harvested per plot; averaged by terrace, 4 plants averaged, same individuals as for treatment; harvested roots were washed with sprayer hose, air dried $20 \mathrm{~min}$, weighed, then hung with ropes to dry in barn; numbers $=\%$ soil amendment; root-obvious rhizome removed, transition zone retained; weights for wet were taken at time of harvest (16Oct2008); weights for dry are from whole plants hung in barn (1Dec2008). Abbreviations in order of appearance: all, all treatments included; avg, mean average; dry\%fresh, dry weight as a percentage of fresh weight; lf/stem, leaf $/$ stem = part of plant growing above soil line; mid, middle terrace; P, peat; root, part of plant growing below soil line; S, steer manure; upr, upper terrace.

Experiment I was planted outside on 14 June 2009. Experiment IV was planted outside on 15 June 2009. Experiment IV had only var. ' $T$ ' plants. Experiments I and IV were exclusively planted with, and replaced with, Apr 2009 cuttings. Experiment IV plants were used to obtain all harvest data for var. ' $T$ ' considered in the body of the paper.

April cuttings were started after losing most of the January cuttings, probably the result of overwatering in the greenhouse. Fertilizers added to the January starting medium made it necessary to greatly reduce time on the mist bench. Plants started in Feb 2008 and Apr 2009 did not receive vermifuge until they were removed from the mist bench. Cuttings planted outside in 2008 had roots that were better established at planting, compared to those of the 2009 transplants.

Prior to planting the original outdoor plantings in June 2009, cuttings of var. ' $L$ ' were arranged into three size classes - small, medium, and large. Distribution by size was randomized using Microsoft Excel (2007). April 2009 cuttings had not developed roots sufficiently well to hang on to media when removed from starter pots, during the original planting. This was unlike root development in cuttings for the 2008 season.

Either or both of two var. ' $T$ ' survivors from a mostly-failed January start for cuttings, and from April cuttings used as replacements in a failed experiment, may have been included in lyophilized material later submitted for out-sourced amino acid and cytotoxicity assays (Kritzer Van Zant 2016a). Details are available for the establishment of other cuttings in 2009 in Kritzer Van Zant (2016a). Because of planting discrepancies, statistical analyses were only made with var. ' $L$ ', considered separately by year, and averaged for each plot.

Replacement of plants in the field: The first month's data from Experiment I were taken from the original plants, planted on 20 June 2009. The second month, data were taken for surviving plants including 11 July replants on 19 July 2009. No plants of either variety that died after 11 July 2009 were replaced. Fifteen of the 44 var. ' $L$ ' plants originally planted in the field in 2009 were dead by the time the second measurements were taken on 19 July. These numbers include the 32 var. ' $L$ ' plants in Experiment I. The var. ' $L$ ' plants from Experiment I which had died by 19 July 2009 are: 4L (Tier I, 1P3S); 6L and 7L (Tier II, 1P3S); 9L, 11L, 12L (Tier I, 3P); 15L (Tier II, 3P); 21L, 23L (Tier II, 5S); 25L, 27L, 28L (Tier I, control); 30L, 31L, 32L (Tier II, control). By 16 August var. ' $L$ ' plant $17 \mathrm{~L}$ (Tier I, 5S) from Experiment I was also dead. By 18 September the longest surviving var. ' $L$ ' plant in Experiment I, 2L (Tier I, 1P3S), was dead. Data from the lost plants was excluded statistically, as imbalances would have been created had they been included.' for line above and two below.

First measurements in 2009 were taken 20 June for Experiment I, and 21 June for Experiment IV. No plants were replaced from the time of the second measurement in July 2009, though losses continued to occur. Last measurements on surviving plants were taken in October both years. In 2008 there were no losses in either the upper or middle terrace and the lowest terrace was not planted with $M$. expansa. In Experiment I with all var. ' $L$ ', by 19 July 2009 , plants were discovered to be missing while taking measurements from: the upper terrace - two lost from the control plot, three each from $1 \mathrm{P} 3 \mathrm{~S}$ and $3 \mathrm{~S}$, and one was lost from $5 \mathrm{~S}$; the middle terrace - three were lost from the control, one from 3P, and two from 5S. No additional plants were lost from Experiment I after 19 July 2009. In Experiment IV with only var. ' $T$ ', in addition to losses discovered 8 July and 
Supplementary Table 2. 2009 harvest data for varieties ' $L$ ' and ' $T$ ' with averages for controls, amendments, and terraces.

\begin{tabular}{|c|c|c|c|c|c|c|c|c|c|}
\hline Var. & Terrace & Treatment & $\begin{array}{l}\text { Whole } \\
\text { plant wet }\end{array}$ & $\begin{array}{l}\text { Whole } \\
\text { Plantdry }\end{array}$ & $\begin{array}{l}\text { Dry } \\
\% \text { fresh }\end{array}$ & $\begin{array}{l}\text { Herbage } \\
\text { dry }\end{array}$ & $\begin{array}{l}\text { Root } \\
\text { dry }\end{array}$ & $\begin{array}{l}\text { Root lgth } \\
\text { dry }\end{array}$ & $\begin{array}{l}\text { Root Diam } \\
\text { dry }\end{array}$ \\
\hline$L$ & Terrace Avg & mid-all & $0.8 \mathrm{~kg}$ & $0.3 \mathrm{~kg}$ & $40.7 \%$ & $0.3 \mathrm{~kg}$ & $0.1 \mathrm{~kg}$ & $28.8 \mathrm{~cm}$ & $10.4 \mathrm{~cm}$ \\
\hline$L$ & Terrace Avg & upr-all & $1.0 \mathrm{~kg}$ & $0.4 \mathrm{~kg}$ & $35.3 \%$ & $0.3 \mathrm{~kg}$ & $<0.1 \mathrm{~kg}$ & $31.3 \mathrm{~cm}$ & $7.0 \mathrm{~cm}$ \\
\hline$L$ & Upr & Control & $0.8 \mathrm{~kg}$ & $<0.1 \mathrm{~kg}$ & $03.8 \%$ & $<0.1 \mathrm{~kg}$ & $<0.1 \mathrm{~kg}$ & $26.6 \mathrm{~cm}$ & $5.6 \mathrm{~cm}$ \\
\hline$L$ & Mid & Control & $0.1 \mathrm{~kg}$ & $0.1 \mathrm{~kg}$ & $45.5 \%$ & $0.03 \mathrm{~kg}$ & $<0.02 \mathrm{~kg}$ & $21.5 \mathrm{~cm}$ & $7.1 \mathrm{~cm}$ \\
\hline$L$ & Treatment Avg & Control & $0.5 \mathrm{~kg}$ & $<0.1 \mathrm{~kg}$ & $08.9 \%$ & $0.02 \mathrm{~kg}$ & $<0.1 \mathrm{~kg}$ & $24.1 \mathrm{~cm}$ & $6.4 \mathrm{~cm}$ \\
\hline$L$ & Upr & $3 \mathrm{P}$ & $1.0 \mathrm{~kg}$ & $0.4 \mathrm{~kg}$ & $42.3 \%$ & $0.40 \mathrm{~kg}$ & $<0.1 \mathrm{~kg}$ & $31.1 \mathrm{~cm}$ & $7.0 \mathrm{~cm}$ \\
\hline$L$ & Mid & $3 \mathrm{P}$ & $1.1 \mathrm{~kg}$ & $0.4 \mathrm{~kg}$ & $41.0 \%$ & $0.39 \mathrm{~kg}$ & $<0.1 \mathrm{~kg}$ & $36.7 \mathrm{~cm}$ & $7.4 \mathrm{~cm}$ \\
\hline$L$ & Treatment Avg & $3 \mathrm{P}$ & $1.0 \mathrm{~kg}$ & $0.4 \mathrm{~kg}$ & $41.4 \%$ & $0.39 \mathrm{~kg}$ & $<0.1 \mathrm{~kg}$ & $33.9 \mathrm{~cm}$ & $7.2 \mathrm{~cm}$ \\
\hline$L$ & Upr & $1 \mathrm{P} 3 \mathrm{~S}$ & $1.6 \mathrm{~kg}$ & $0.8 \mathrm{~kg}$ & $47.2 \%$ & $0.70 \mathrm{~kg}$ & $0.1 \mathrm{~kg}$ & $38.0 \mathrm{~cm}$ & $8.4 \mathrm{~cm}$ \\
\hline$L$ & Mid & $1 \mathrm{P} 3 \mathrm{~S}$ & $1.4 \mathrm{~kg}$ & $0.5 \mathrm{~kg}$ & $39.4 \%$ & $0.47 \mathrm{~kg}$ & $0.1 \mathrm{~kg}$ & $40.0 \mathrm{~cm}$ & $8.5 \mathrm{~cm}$ \\
\hline$L$ & Treatment Avg & 1P3S & $1.5 \mathrm{~kg}$ & $0.7 \mathrm{~kg}$ & $43.6 \%$ & $0.58 \mathrm{~kg}$ & $0.1 \mathrm{~kg}$ & $39.0 \mathrm{~cm}$ & $8.5 \mathrm{~cm}$ \\
\hline$L$ & Upr & $5 \mathrm{~S}$ & $0.6 \mathrm{~kg}$ & $0.2 \mathrm{~kg}$ & $36.5 \%$ & $0.20 \mathrm{~kg}$ & $<0.1 \mathrm{~kg}$ & $29.7 \mathrm{~cm}$ & $6.9 \mathrm{~cm}$ \\
\hline$L$ & Mid & $5 \mathrm{~S}$ & $0.7 \mathrm{~kg}$ & $0.3 \mathrm{~kg}$ & $40.9 \%$ & $0.24 \mathrm{~kg}$ & $0.1 \mathrm{~kg}$ & $17.0 \mathrm{~cm}$ & $18.4 \mathrm{~cm}$ \\
\hline$L$ & Treatment Avg & $5 \mathrm{~S}$ & $0.7 \mathrm{~kg}$ & $0.3 \mathrm{~kg}$ & $38.8 \%$ & $0.22 \mathrm{~kg}$ & $<0.1 \mathrm{~kg}$ & $23.3 \mathrm{~cm}$ & $12.7 \mathrm{~cm}$ \\
\hline$T$ & Terrace Avg & mid-all & $0.3 \mathrm{~kg}$ & $0.1 \mathrm{~kg}$ & $50.0 \%$ & $0.11 \mathrm{~kg}$ & $<0.1 \mathrm{~kg}$ & $21.6 \mathrm{~cm}$ & $7.0 \mathrm{~cm}$ \\
\hline$T$ & Terrace Avg & upr-all & $0.1 \mathrm{~kg}$ & $<0.1 \mathrm{~kg}$ & $40.0 \%$ & $0.02 \mathrm{~kg}$ & $<0.1 \mathrm{~kg}$ & $15.1 \mathrm{~cm}$ & $4.4 \mathrm{~cm}$ \\
\hline$T$ & Upr & $2 \mathrm{P}$ & $\dagger$ & $\dagger$ & $\dagger$ & $\dagger$ & $\dagger$ & $\dagger$ & $\dagger$ \\
\hline$T$ & Mid & $2 \mathrm{P}$ & $0.2 \mathrm{~kg}$ & $0.1 \mathrm{~kg}$ & $42.1 \%$ & $0.07 \mathrm{~kg}$ & $<0.1 \mathrm{~kg}$ & $21.2 \mathrm{~cm}$ & $5.6 \mathrm{~cm}$ \\
\hline$T$ & Treatment Avg & $2 \mathrm{P}$ & $0.2 \mathrm{~kg}$ & $0.1 \mathrm{~kg}$ & $42.1 \%$ & $0.07 \mathrm{~kg}$ & $<0.1 \mathrm{~kg}$ & $21.2 \mathrm{~cm}$ & $5.6 \mathrm{~cm}$ \\
\hline$T$ & Upr & $4 \mathrm{~S}$ & $0.1 \mathrm{~kg}$ & $<0.1 \mathrm{~kg}$ & $40.0 \%$ & $0.02 \mathrm{~kg}$ & $<0.1 \mathrm{~kg}$ & $15.1 \mathrm{~cm}$ & $4.4 \mathrm{~cm}$ \\
\hline$T$ & Mid & $4 \mathrm{~S}$ & $0.3 \mathrm{~kg}$ & $0.2 \mathrm{~kg}$ & $52.9 \%$ & $0.15 \mathrm{~kg}$ & $<0.1 \mathrm{~kg}$ & $21.9 \mathrm{~cm}$ & $8.3 \mathrm{~cm}$ \\
\hline$T$ & Treatment Avg & $4 \mathrm{~S}$ & $0.2 \mathrm{~kg}$ & $0.1 \mathrm{~kg}$ & $50.0 \%$ & $0.08 \mathrm{~kg}$ & $<0.1 \mathrm{~kg}$ & $18.5 \mathrm{~cm}$ & $6.4 \mathrm{~cm}$ \\
\hline
\end{tabular}

Notes: averaged by terrace, 4 plants averaged for var. ' $L$ ', 2 for var. ' $T$ ' $\dagger$, same individuals as for treatment; averaged by treatment, 2 plants averaged $\dagger$, one harvested per plot; †exception-No var. 'T plants survived past July 8, 2009, so no harvest weight was given for $2 \%$ peat upper terrace; both varieties were barn dried to the $9^{\text {th }}$ day after harvest when weighed; harv ested roots were washed with spray er hose, air dried $20 \mathrm{~min}$, weighed, then hung with ropes to dry in barn; lengths and diameters of roots were measured on dry material; numbers $=\%$ soil amendment; root—obvious rhizome removed, transition zone retained; var. ' $L$ ' harvest data is from experiment $I$ in 2009 . Var. ' $T$ harvest data is from experiment IV Weights for wet taken at time of harvest (19Oct2008); weights for dry from whole plants hung in barn (280ct2008). Abbreviations in order of appearance: all, all treatments included; avg, mean average; dry\%fresh, dry weight as a percentage of fresh weight; leaf/stem, part of plant growing above soil line (lf/stem); mid, middle terrace; $\mathrm{P}$, peat; root, part of plant growing below soil line; S, steer manure; upr, upper terrace.

soon replaced, one more plant was discovered dead on 16 Aug from the $4 \mathrm{~S}$ upper terrace plot. In addition, another plant that had been suspected to be dead in the same plot on 8 July was missing without any remnant by 19 July. That last plant was also not replaced.

Fertilizer: Individual plants, planted outdoors 2 July 2008 and 1 July 2009, received one pint of mushroom composted horse manure at the time of planting. In 2009, the same batch of manure was used to fertilize the plants. However, by 2009 the manure pile had been exposed to the elements and resultant leaching for an additional year. Mushroom composted horse manure was added to each plant by first digging a small hole, then stirring the manure into the sand or using a little more sand to cover the manure, then placing cuttings on top.

Chemical fertilizers were not used. M. expansa has potential as a superfood for the designer health product industry. If the plants can be grown organically, they will have broader appeal for this market. In 2008 leaves of the plants were treated at planting time with a natural latex-based commercial preparation, to reduce damage from pests. Latex was applied because some of the young plants lost in 2007 in native soil had been badly damaged from herbivory, suspected to have been the work of small animals. As the latex clogged a sprayer, it was hand applied. As a result, the substance was probably applied too thickly. As applying latex seemed to do more harm than good, it was not used again. Fortunately, most plants soon pro- duced other leaves which were not treated, allowing them to survive.

Nitrogen - Plots were tested for nitrogen concentrations with samples taken from different plots and terraces in 2011. In 2012, a subset of these samples, from the first terrace, including the plot types for the repeated 2008 and 2009 experiments, were submitted for nitrogen testing to the Soil and Plant Testing Laboratory at University of Missouri Extension (http://soilplantlab.missouri.edu/soil). Nitrogen concentrations for different plots varied, though not in any pattern that correlated with plot amendments at the time of construction. No additional samples from these plots were tested further for nitrogen levels.

Weeds and Weeding - Weedy species inhabiting plots varied sufficiently to show effects, carried over from the original treatments. These differences in species communities, appeared to be independent of whether the original additions of steer manure and peat were still present. Weed taxa present in each plot may indicate differences in aggregate structure and/or water-holding capacity of the plots. Weeding was done, with hand tools, when data were collected. Plants were weeded monthly in 2009 instead of bi-monthly as they had been in 2008. More detail on plot differences can be found in Kritzer Van Zant (2016a) along with information on efforts to plant in native soils from 2007 to 2011.

Fencing - Fencing varied from year to year and made little 


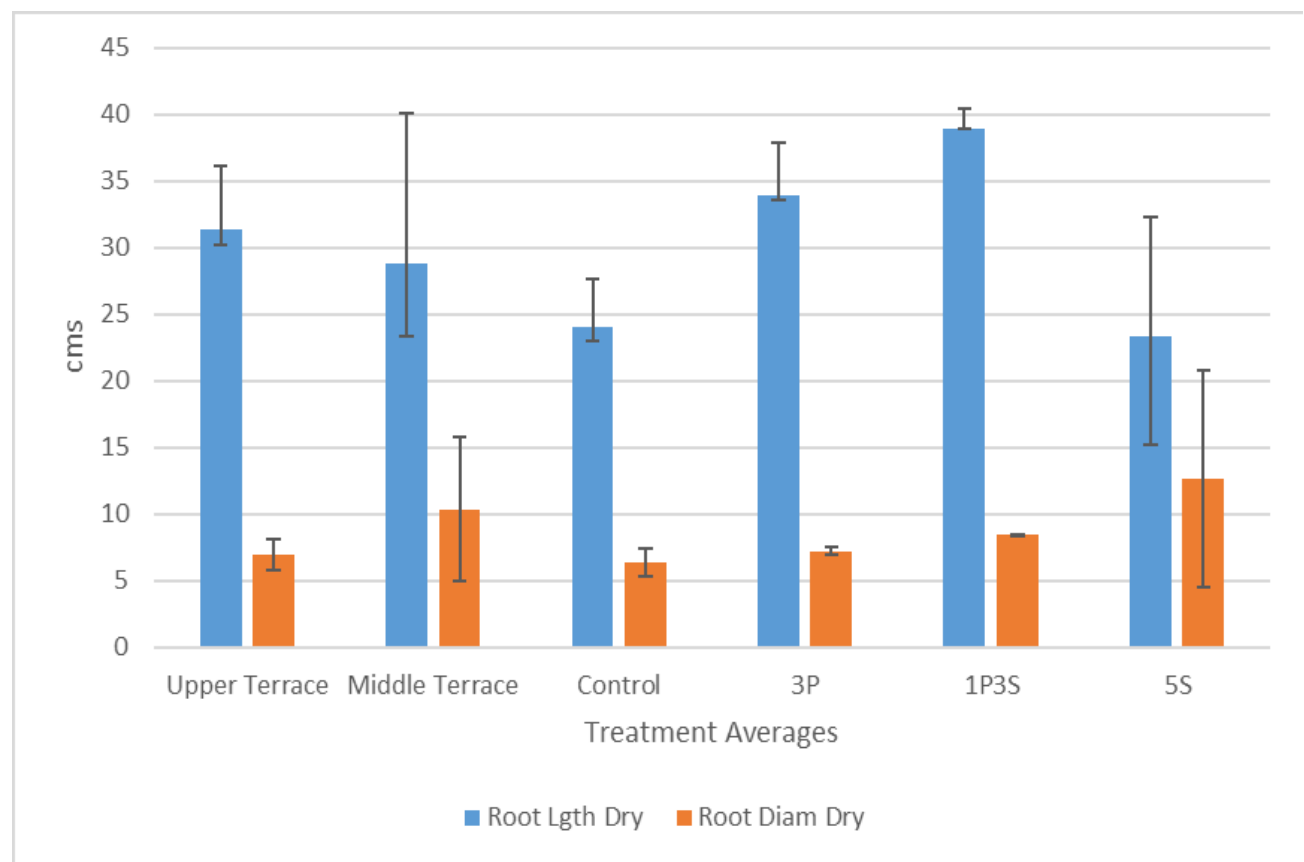

Supplementary Figure 1. Chart of 2009 var. 'L' harvest root size nine days dry with SDs, grown in outdoor sand plots. X-axis: treatments: upper terrace and middle terrace, soil amended plot types control, 3P, 1P3S, 5S. y-axis: lengths in cms. Abbreviations: control was all sand; 3P, 3\% peat; 1P3S, COA 1\% peat and $3 \%$ steer manure; $5 \mathrm{~S}, 5 \%$ steer manure.

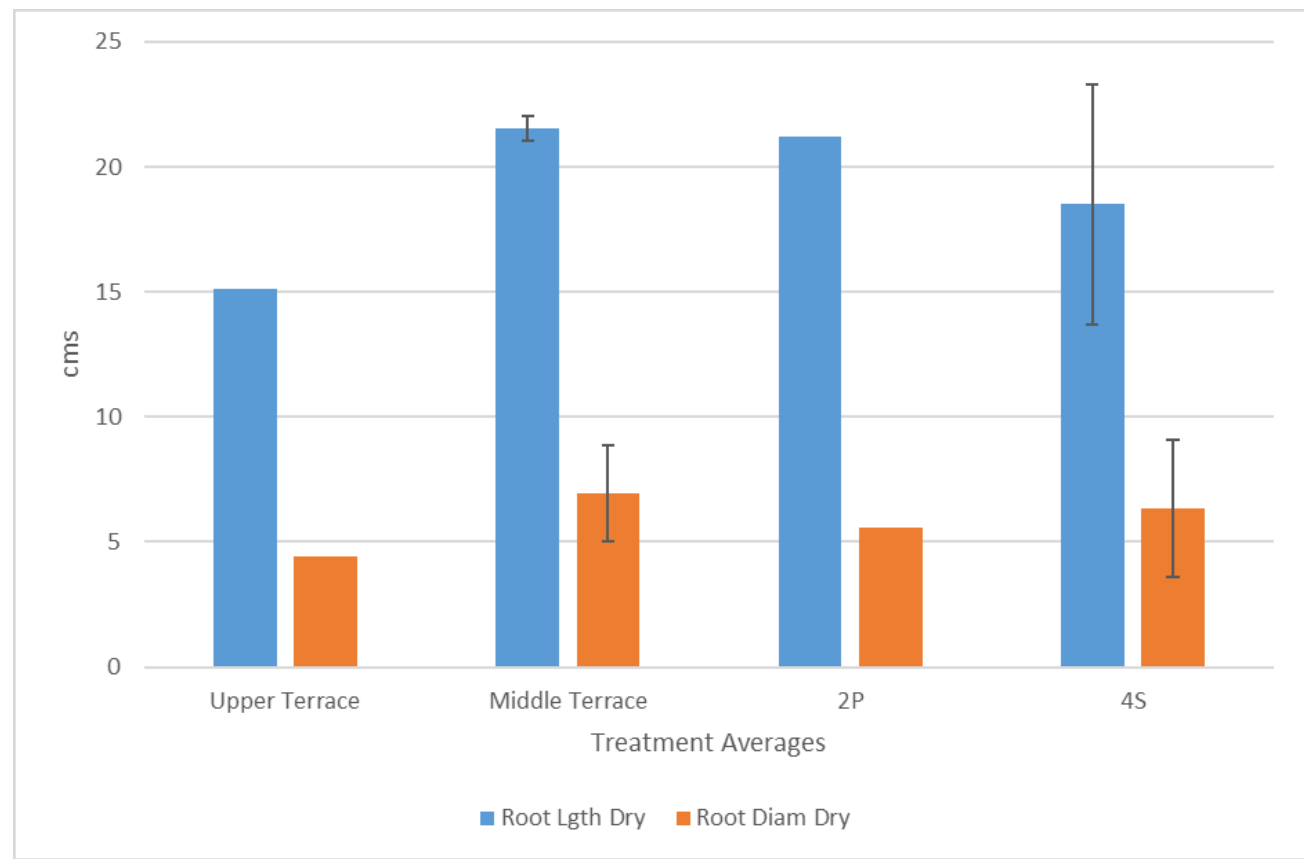

Supplementary Figure 2. Chart of 2009 var. ' $T$ ' harvest root size nine days dry with SDs, grown in outdoor sand plots. $\mathrm{X}$-axis: treatments: upper terrace and middle terrace, soil amended plot types $2 \mathrm{P}$ and 4S. y-axis: lengths in cms. Abbreviations: $2 \mathrm{P}, 2 \%$ peat; $4 \mathrm{~S}, 4 \%$ steer manure. 


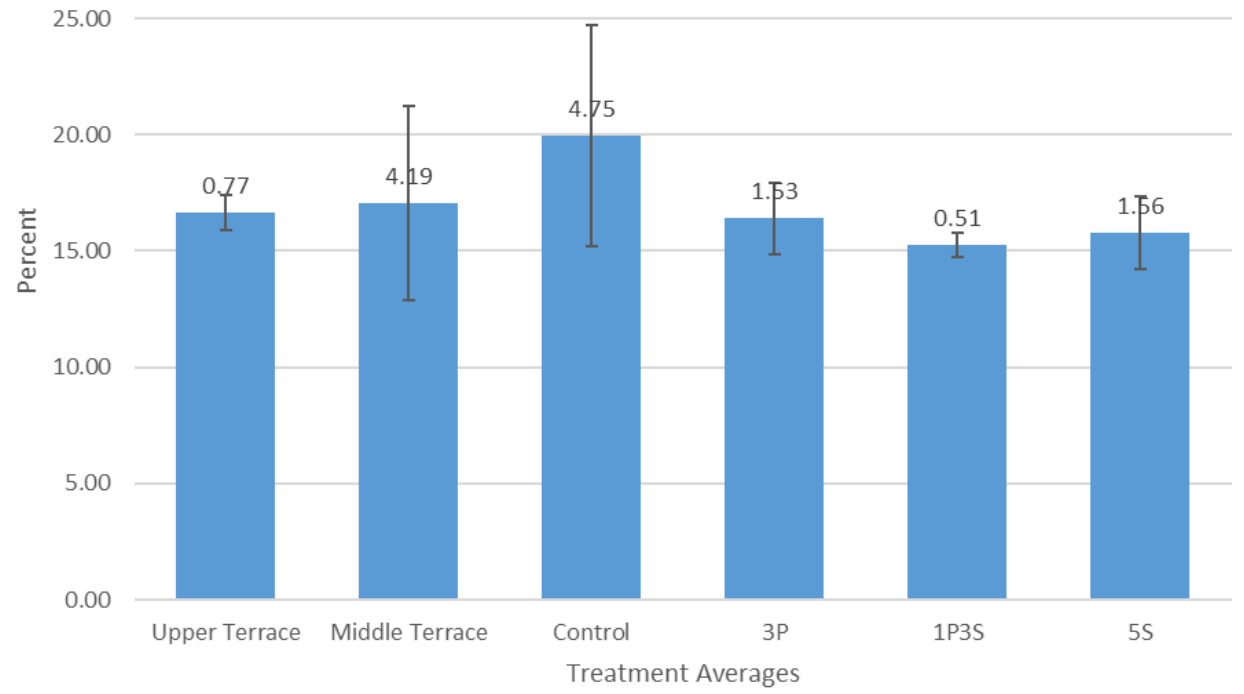

Supplementary Figure 3. Chart of 2008 var. ' $L$ ' $>30$ days dry as a $\%$ of fresh weight with SDs, grown in outdoor sand plots. X-axis: Treatments: upper terrace and middle terrace, soil amended plot types control, 5S, 3P, 1P3S, control. y-axis: percent. Abbreviations: 5S, 5\% steer manure; 3P, 3\% peat; $1 \mathrm{P} 3 \mathrm{~S}$, combined organic amendments $1 \%$ peat and $3 \%$ steer manure; control was all sand.

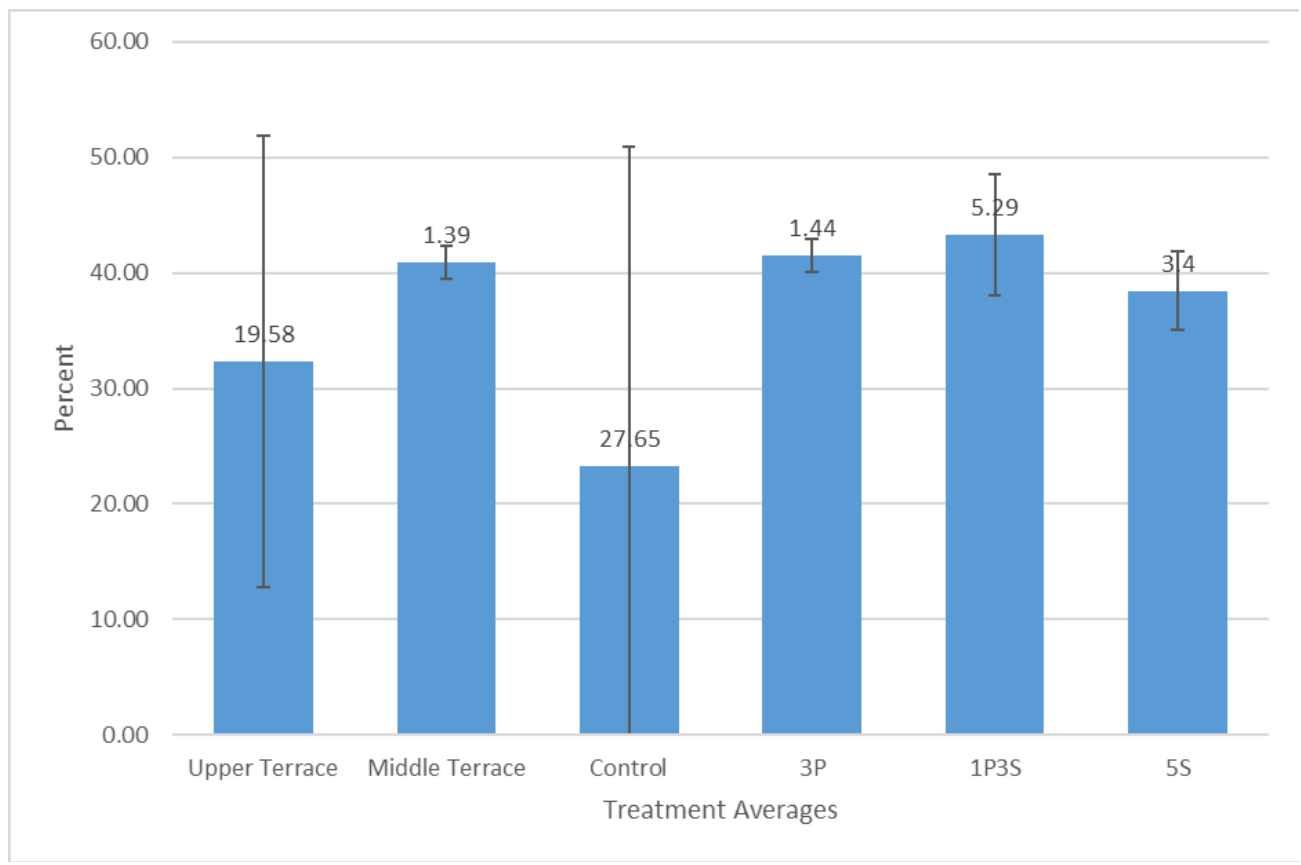

Supplementary Figure 4. Chart of 2009 var. ' $L$ ' nine days dry as a \% of fresh weight with SDs, grown in outdoor sand plots in 2009. x-axis: Treatments: upper terrace and middle terrace, soil amended plot types control, 3P, 1P3S, 5S. y-axis: percents. Abbreviations: control was all sand; 3P, 3\% peat; 1P3S, combined organic amendments $1 \%$ peat and $3 \%$ steer manure; $5 \mathrm{~S}, 5 \%$ steer manure. 


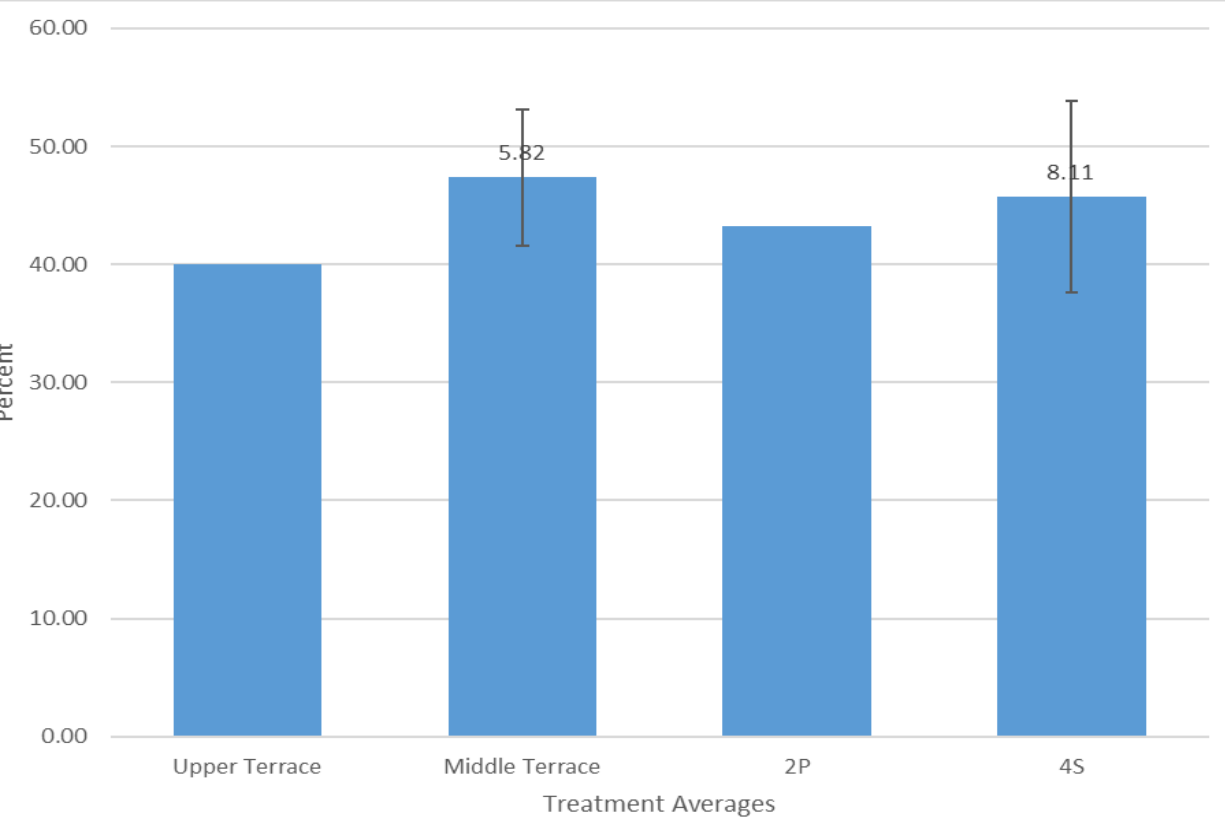

Supplementary Figure 5. Chart of 2009 var. ' $T$ ' nine days dry as a \% of fresh weight with SDs, grown in outdoor sand plots in 2009. x-axis: Treatments: upper terrace and middle terrace, soil amended plot types control, 2P, 4S. y-axis: percent. Abbreviations: 2P, 2\% peat; 4S, 4\% steer manure.

difference within terraces. Plots used in Experiment I had been fenced early in the 2008 growing season and remained so in 2009. More details on fencing for these years, as well as information on native soil attempts from 2007 to 2011 are available (Kritzer Van Zant 2016a and 2016a).

Precipitation - Both 2008 and 2009 were among the wettest years recorded for southern Illinois as of 2009. Precipitation data for southern Illinois, used to interpret our data, were taken from the Illinois State Water Survey Prairie Research Institute (Angel 2008, 2009, 2010a, 2010b). Specific data for October from Carbondale Illinois Airport/NOAA (2008, 2009, 2010) were also examined. It should be considered that plants were no longer being measured after mid-October. The general precipitation for southern Illinois averaged for each month in inches, as given for the 2008-2010 growing seasons from May to October shows: 2008-May 7.28, June 2.55, July 5.68, Aug 2.33, Sep 3.79, Oct 2.22; Total for season 23.85. 2009-May 6.81, June 4.57, July 5.59, Aug 3.57, Sep 3.32, Oct 10.59; Total for season 34.45 .

Other than rain, water was given to plants outdoors only at the time of planting, if at all. More detailed information on precipitation is in Kritzer Van Zant (2016a and 2016a Appendix B-3). This includes summarization of published analyses of the significance of southern Illinois weather in the years when $M$. expansa was planted there (Angel 2010a, 2010b; Carbondale Illinois Airport/NOAA 2009; Changnon and Black 2009; Daily Republican 2011). Most final data for 2009 were taken 18 Oct. Details are in Kritzer Van Zant (2016a and 2016a Appendix B-3). Axial shoot data was taken 21 Oct after that data point was discovered to be missing during computer entry. Frost im- pacted above-ground parts of plants by 18 Oct, partially wilting stems and leaves, and causing discoloration. Despite the slight frost, final measurements for 2009 are thought to be accurate.

Lyophilization - Leaves with attached fine stems were lyophilized for additional testing (Kritzer Van Zant 2016a and 2016a Appendix B-3). Roots lyophilized for additional testing had attached epidermi and retained connected enlarged stems. One var. ' $L$ ' plant from each of four of the eight original soil treatments, 5S, 3P 1P3S, and the control, were lyophilized in 2008. Harvested and lyophilized var. ' $T$ ' roots were from $2 \mathrm{P}$ and $4 \mathrm{~S}$ plots in 2009.

Plants of both varieties were brought into the greenhouses from field plots and transplanted into pots on 1 Nov 2009. These plants continued growing until processed for lyophilization. They were repotted from the field at the HRC greenhouse, in media consisting of $40 \%$ vermiculite, $40 \%$ perlite, $15 \%$ peat and 5\% vermifuge. At first these plants dropped most of their leaves in the greenhouse. Soon, most of them leafed out and appeared to thrive indoors.

Var. ' $T$ ' plants numbered T3, T8, and T10, all died in the greenhouse prior to harvest for lyophilization, leaving an above-ground portion in the pot. These three plants were not discarded until checked for root remnants at the time of harvest for lyophilization. When $M$. expansa dies it is rare to find any remnant of the roots. Of these three, only T8 (5S) had intact root remaining. This root remnant was stored in ethanol in a clear glass vial. Some of the root epidermis fell away during handling, exposing possible fibers in the transition zone between root and stem. Perhaps in the future T8 root remnants can be examined to identify which fungi and/or other micro- 


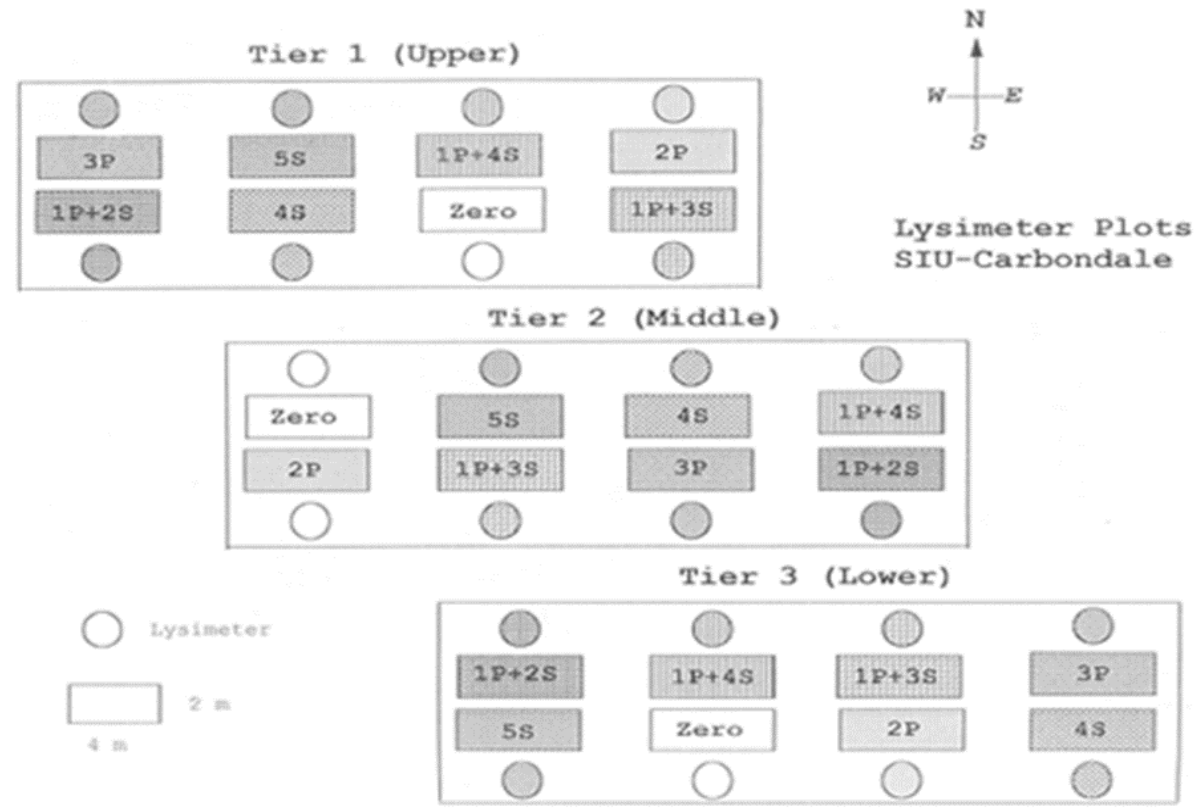

\begin{abstract}
Supplementary Figure 6. Terrace plot map Horticultural Research Center (HRC) SIU-C, random blocks of $2 \mathrm{~m} \mathrm{x} 4 \mathrm{~m}$ plots, repeating on three terraces. Each plot received one of eight levels of soil amendment. Tier 1 is the highest terrace, closest to the top of the hill, closest to the access road within $\mathrm{HRC}$, and therefore closest to nearly daily human activity. Tier 1 is the site of the var. ' $L$ ' repeat experiments in 2008 and 2009. Tier 3 is the lowest terrace along the hillside, most isolated from human activity, though closest to the road adjacent to and outside of HRC. Tier 3 is the site of the all var. ' $T$ ' experiment, from which harvest data for var. ' $T$ ' was taken. Numbers indicate percentage of each soil amendment used for that plot at the time of construction. Abbreviations: P, peat; S, steer manure; zero, all-sand control.
\end{abstract}

organisms infected it, and/or whether there are possible fungal allies present.

In late winter/spring 2010, specimens were harvested in batches for lyophilization from the plants moved from the field into the greenhouse at the end of the 2009 growing season, beginning 19 Feb 2010. Methods for lyophilization are given in greater detail in Kritzer Van Zant (2016a).

\section{Additional Descriptions of Positive Data and Strong Trends in Negative Data}

Additional descriptions-ANOVAs 2008: Figures of plant height and longest axial shoot length for COA reveal that percent increases for all treatments gradually increased over the all-sand controls (Figures 1 and 5; Kritzer Van Zant 2016a).

The 1\% Peat combined with 3\% Steer Manure treatment had the least effect on plant height until it increased to second place at the time of harvest in mid-October. However, $1 \%$ Peat combined with 3\% Steer Manure retained the lowest increase over the control for longest axial shoot length through the season.

ANOVAs for the 2008 growth data, for the independent variables Steer Manure and Terrace were neither highly significant nor significant for any dependent variable (Table 1).

Additional descriptions-ANOVAs 2009: COA for lamina with petiole length exhibited a great deal of inconsistency through the growing season, though the control was lowest until the time of harvest in mid-October (Kritzer Van Zant 2016a).
ANOVAs for the 2009 growth data, for the independent variables peat and steer manure, were neither highly significant nor significant for any dependent variable (Table 2).

The upper terrace consistently had more herbivory coded 0 , 1 through the growing season, though only slightly so in midJuly and about $60 \%$ more than the middle terrace when differences were greatest. Greatest differences occurred at the time of harvest in mid-October (Figure 92 in Kritzer Van Zant 2016a).

Additional descriptions - Interaction of time with independent variables 2008: Interaction of time with peat, steer manure, and terrace, for the 2008 growth data, had no significance for any dependent variable (Table 1).

Additional descriptions - Interaction of time with independent variables 2009: Interaction of time with COA for the 2009 growth data was not highly significant for any dependent variable.

Interaction of time with steer manure, and with terrace, for the 2009 growth data, was neither highly significant nor significant for any independent variable (Table 2).

\section{Discussion and Additional Points}

Discussion, additional points-Cuttings: Poorer root development of cuttings at the time of outdoor planting in 2009 compared to 2008 was unsurprising. This is because most of the 2009 transplants were younger at planting time than the 2008 transplants had been. Adding vermifuge initially when starting 
cuttings, was sometimes desirable when working with stock plants, as this often produced dense, bonsai-like habits in young plants, and faster initial growth. However, the ability to tolerate the richer and wetter media appears to be relative to overall heat and humidity inside the greenhouse. In 2009, starting stock plants by using vermifuge when initiating cuttings in 2009 seemed to have contributed to higher mortality in cuttings and less root development at the time of field planting, compared to 2008. Though replacements plants in 2009 had less time in the field than originally planted individuals, this discrepancy was somewhat cancelled out by the replacements having stronger roots when planted outside than their predecessors earlier in the same year. Var. ' $L$ ' plants in the repeated experiments were not replaced, and no replacements were measured for harvest data for either variety. Therefore, replacements had no impact on the ANOVAs, or interpretation of harvest data.

Discussion, additional points-Field Growth Variables: At least some plants of each variety grew to maturity in at least one of each plot type utilized in both 2007 and 2008.

Lamina width over lamina with petiole length was significant for all four independent variables in 2008: COA; peat; steer manure; and terrace. The inverse relationship, lamina with petiole length over lamina width, was significant only for terrace, and only in 2008. No other ratio data had significance for any variable. Lamina width over lamina with petiole length was not more informative than other characters. For these reasons, all ratios were dropped from analysis in 2009.

Discussion, additional points-ANOVAs: ANOVAs for growth data for the independent variables steer manure in 2008 and 2009, terrace in 2008, and peat in 2009, had no significance for any dependent variable. See discussion immediately above for consideration of terrace in ratio data.

Discussion, additional points - Interaction of time with independent variables: Interaction of time with any independent variable, for the growth data, was consistently not highly significant, and consistently not significant between years, for any combination of independent and dependent variables. Interaction of time with the independent variable peat, for the growth data, had no significance for any dependent variable in 2008. Interaction of time with either independent variable steer manure or terrace, for the growth data, were not significant for any dependent variable in 2008 or 2009. Thus, there was a consistent lack of significance in 2008 and 2009 for the interaction of time with both independent variables steer Manure and terrace.

Discussion, additional points-Herbivory: Herbivory coded 0,1 was not significant in 2008, for COA for time.

Though Herbivory coded 0, 1 in 2008 and Herbivory coded 0-4 in 2009 were both significant for peat for time, Herbivory coded 0, 1 in 2009 had no significance for peat.

Discussion, additional points-Harvest: Variety ' $L$ ' entire plants lost much more water weight during drying in 2008 than in 2009. This occurred, despite less rain across the 2008 growing season. This was true for entire plants from both the middle and upper terraces. There was an inverse relationship of water available in the final month of growth and water lost when var. ' $L$ ' was dried. Extra rain in 2009 may have allowed var. ' $L$ ' to increase its solid mass even more than its water mass.
Looking at the individual terraces for entire plant wet and dry weights, upper terrace whole wet plants in 2008 were about $50 \%$ heavier than dried whole plants from the middle terrace for plots with the same soil amendments. These differences between 2008 and 2009 var. ' $L$ ' can be seen for every treatment for dry entire plant weights. For var. ' $L$ ' averaged entire dry plants, the control, $3 \mathrm{P}$ and $1 \mathrm{P} 3 \mathrm{~S}$ plots were about $1 / 4$ of a kilo heavier, and $5 \mathrm{~S}$ plots were about $1 / 2$ of a kilo heavier, in 2008 compared to 2009.

For averaged entire plants in 2009, 2P plots of var. ' $T$ ' and $3 P$ plots of var. ' $L$ ', retained nearly the same percentage of dryto-wet mass in 2009. For averaged entire plants in 2009, $4 \mathrm{~S}$ plots of var. ' $T$ ' retained $11 \%$ more mass upon drying than $5 \mathrm{~S}$ plots of var. ' $L$ '. Comparing the all peat plots between varieties in 2009 for the averaged dry weights of the harvested entire plants, $3 \mathrm{P}$ grown var. ' $L$ ' weighed $0.4 \mathrm{~kg}$, compared to $2 \mathrm{P}$ grown var. 'T' which weighed less than $0.1 \mathrm{~kg}$. Comparing the all steer manure plots between varieties in 2009 for the averaged dry weights of the harvested entire plants, $5 \mathrm{~S}$ grown var. ' $L$ ' weighed $0.3 \mathrm{~kg}$, while $4 \mathrm{~S}$ grown var. ' $T$ ' weighed less than $1 / 2$ of that weight at $0.1 \mathrm{~kg}$.

Averaged dry weights for leaves and stems for the upper terrace were nearly double those of the middle terrace in 2008. In 2009 , averaged weights for dried leaves and stems of var. ' $L$ ' were again greater for the upper terrace though much less than for 2008. For var. ' $T$ ' in 2009 , the averaged dried leaves and stems weighed less for the upper terrace. This is the opposite of var. ' $L$ ' in 2009. Var. ' $T$ ' had much lower weights than var. ' $L$ ' that year. Both varieties had considerable weight differences between terraces in 2009 for averaged dried roots.

In 2008 and 2009 dry leaf and stem material of each variety weighed more than dry root material with what appears to be a single exception (Supplementary Table 2). This was true for both terraces and all plot types tested. The seeming exception was for var. ' $L$ ' for control plots in 2009, which had the same averaged weight for dried leaf and stem as for dried root. Individual plots and terraces on average were also higher for dry weights of leaf and stem over root, for both varieties in 2009.

In 2008 for var. ' $L$ ', the heaviest averaged, dried, entire plant, leaf and stem, and root portions, were in the upper terrace relative to the middle terrace. In 2009 var. ' $L$ ' averaged, dried, entire plant, and dried leaf and stem portions, were both heavier again in the upper terrace. However, the averaged dried root material of variety ' $L$ ' was heavier in the middle terrace as were the dried averaged entire plant, stem and leaf portion, and root portion, of var. ' $T$ ' in 2009. Therefore, heaviest dry weights by terrace in 2009 , were mostly inversed for the two varieties. For var. ' $L$ ' in 2009 root lengths were longer on the upper terrace though for var. ' $T$ ' root lengths were longer on the middle terrace. For both varieties in 2009 root diameters were wider on the middle terrace.

Averaged dried var. ' $L$ ' material in 2008 , by plot type for both the dry entire plant and the dried leaf and stem portions, were heaviest in the $5 \mathrm{~S}$ plots and lightest in the control plots.

Averaged dried var. ' $L$ ' material in 2008 by plot type for the dried root portions was again heaviest in the $5 \mathrm{~S}$ plots though lightest in both the control plots and 1P3S plots. Averaged dried 
var. ' $L$ ' material in 2009 by plot type for the dry entire plant, leaf and stem portion, and root portion, was heaviest in the 1P3S plots and lightest in the control plots.

Thus the var. ' $L$ ' 2008 and 2009 material were somewhat similar in having the lightest dried root material primarily in the control plots. However, there was a lack of resolution for why 1P3S plots shared the lightest averaged weights with the control in 2008 yet had the heaviest averaged weights for the same variety in 2009. Examining this in more detail, 1P3S plots in both the upper and middle terraces in 2008, had the lightest dry var. ' $L$ ' entire plants, leaf and stem portions, and root portions. For the $5 \mathrm{~S}$ plots for var. ' $L$ ', whole dry plants, and dry leaf and stem portions, were lighter in both terraces in 2009. However, the $5 \mathrm{~S}$ plots for var. ' $L$ ' had root portions which were lighter in the middle terrace in 2008 , though lighter in the upper terrace in 2009.

Averaged dried var. ' $T$ ' material in 2008 by plot type was heavier for the entire plant, leaf and stem portion, and root portion, in the $4 \mathrm{~S}$ plots over the $2 \mathrm{P}$ plots. This heaviest dry weight data for var. ' $T$ ' in 2009 was only similar to the var. ' $L$ ' harvest results for the all peat and all steer manure averaged plot types in 2008, which again contradicted the var. ' $L$ ' 2009 dry weight results.

For var. ' $L$ ' in 2009 averaged root length was longest in the 1P3S plots and shortest in the 5S plots. For var. ' $L$ ' in 2009 averaged root diameter was greatest in the $5 \mathrm{~S}$ plots and least in the control plots. Thus, there was an inverse relationship for var. ' $L$ ' in 2009 between root length and diameter in the $5 \mathrm{~S}$ plots.

For var. ' $T$ ' in 2009 averaged root length was longest in the 2P plots and shortest in the 4S plots. For var. ' $T$ ' in 2009 averaged root diameters were greatest in the $4 \mathrm{~S}$ plots and least in the $2 \mathrm{P}$ plots. As the relationship for var. ' $T$ ' at harvest in 2009 between root length and root diameter were in an inverse relationship between the $2 \mathrm{P}$ and $4 \mathrm{~S}$ plots, and as $5 \mathrm{~S}$ for var. ' $L$ ' and $4 \mathrm{~S}$ for var. ' $T$ ' were the densest plot types in this study, it appeared that denser, richer soils favored a shorter broader root shape for $M$. expansa. This may indicate that the shape of $M$. expansa roots can change along with changes in soil density.

\section{Harvest Data Complete Tables and Additional Graphs}

Harvest Data Tables: There were insufficient harvest data for statistical analysis beyond presenting means from the same plot types and graphs of the data in these charts with error bars representing standard deviations. Most of this data are means from two plants unless only one plant was available for a particular plot type. Eight figures are based on Supplementary Tables 1 and 2. Three are in the body of the paper (Figures 4, 5, and 6) show the relationships in $\mathrm{kg}$ between plot types and terraces with measurements taken at harvest time, respectively for var. ' $L$ ' in 2008 (Figure 4), var. ' $L$ ' in 2009 (Figure 5), and var. ' $T$ ' in 2009 (Figure 6). Additional figures based on these tables show the relationships for the same harvested plants measured in cm only in 2009, for variety ' $L$ ' (Supplementary Figure 1) and var. ' $T$ ' (Supplementary Figure 2 ). Charts showing percentage the differences in fresh and dry whole plant weights from these tables, are for var. ' $L$ ' in 2008 (Supplementary Figure 3), var. ' $L$ ' in 2009 (Supplementary Figure 4) and var. ' $T$ ' in 2009 (Supplementary Figure 5). Where only one plant was available for harvest from a particular plot type, standard deviations could not be computed in the charts. 